\title{
Possible impacts of Indian Ocean Dipole mode events on global climate
}

\author{
N. H. Saji ${ }^{1,3, *}$, T. Yamagata ${ }^{1,2}$ \\ ${ }^{1}$ Institute for Global Change Research, 3173-25 Showa-machi, Kanazawa, Kanagawa 236-0001, Japan \\ ${ }^{2}$ Department of Earth and Planetary Sciences, The University of Tokyo, Tokyo 113-0033, Japan \\ ${ }^{3}$ Present address: International Pacific Research Center, 2525 Correa Road, Honolulu, Hawaii 96822, USA
}

\begin{abstract}
Impacts of Indian Ocean Dipole mode (IOD) events on global climate are estimated by correlation/regression analysis. The analysis examined land rain and temperature and 3-dimensional atmospheric variables for a 42 yr period from January 1958 to December 1999. The correlation between IOD and the El Niño Southern Oscillation (ENSO) is accounted for using the multiple regression technique. We used partial correlation coefficients to describe the unique contribution of IOD to climate variability, independent of ENSO. In the Indian Ocean rim countries, IOD is associated with significant temperature and rain variability manifesting 2 large-scale patterns. In one, land temperature and rain are anomalously high over countries west of the Indian Ocean and anomalously low to its east. In the second pattern, enhanced rainfall is found over the Asian monsoon trough, extending from Pakistan up to southern China. Also noted are IOD impacts on several regions remote from the Indian Ocean. Strong correlation is found over Europe, northeast Asia, North and South America and South Africa concurrent with IOD events. Over these regions, positive IOD events are associated with warm land surface anomalies and reduced rainfall. The troposphere above the Indian Ocean exhibits strong variability during IOD events characterized by the following structures: (1) a Walker cell anomaly over the equator; (2) a deep modulation of monsoon westerlies; and (3) a Hadley cell anomaly over the Bay of Bengal. In the extratropics, IOD is associated with equivalent barotropic geopotential anomalies. These assume annular structure in the northern hemisphere, but Rossby wave train structure in the southern hemisphere.
\end{abstract}

KEY WORDS: Dipole Mode Index $\cdot$ Teleconnection pattern $\cdot$ Multiple regression analysis Resale or republication not permitted without written consent of the publisher

\section{INTRODUCTION}

Sea-surface temperature (SST) in the tropical Indian Ocean exhibits 2 distinct anomaly patterns on interannual time scales. In one, the SST anomaly over the entire basin is uniformly modulated lagging the El Niño Southern Oscillation (ENSO) (Pan \& Oort 1983, Wallace et al. 1998) and likely results from the thermodynamic adjustment of the mixed layer to ENSOinduced flux changes (Klein et al. 1999, Chiang \& Sobel 2002).

A second pattern exhibits anomalous and strong zonal SST gradients in the equatorial regions, phaselocked to the boreal summer and fall (Reverdin et al. 1986, Hastenrath et al. 1993, Vinayachandran et al.
1999, Saji et al. 1999, Webster et al. 1999, Murtugudde et al. 2000). In this paper we will deal with this pattern of SST variability exclusively. Since the SST gradient anomaly manifests a distinct dipole structure during the boreal fall (Saji \& Yamagata 2003), we will refer to it as the Indian Ocean Dipole mode (IOD) event.

SST anomalies during IOD events are strongly coupled to surface wind anomalies in the central equatorial Indian Ocean (Saji et al. 1999, Saji \& Yamagata 2003). Surface winds reverse direction from westerlies to easterlies during the peak phase of positive IOD events (Rao et al. 2002), i.e. when the SST anomaly is cool in the east and warm in the west and the zonal SST gradient is reversed relative to normal years. The wind anomalies also strongly influence sea level (Rao et al. 
2002) and thermocline anomalies (Feng \& Meyers 2003) likely through oceanic adjustment processes (T. Shinoda, H. H. Hendon, M. A. Alexander unpubl.). Sea level is anomalously lowered in the east and raised in the central and western Indian Ocean during positive IOD events. In accordance with theory that predicts a baroclinic oceanic response to wind anomalies in equatorial regions (McCreary \& Anderson 1984), the anomalous thermocline has a sign opposing that of sea level. Simulation of the ocean state during IOD events in a wide variety of oceanic models suggests that the dipole SST pattern is brought about primarily by oceanic processes such as advection, entrainment and upwelling. In particular, in the eastern Indian Ocean the heat budget of the mixed layer is dominated by upwelling and vertical entrainment (Behera et al. 1999; T. Shinoda, H. H. Hendon, M. A. Alexander unpubl.). However, in the western Indian Ocean horizontal advection is an important term, and to some extent so are atmospheric fluxes (Murtugudde et al. 2000, Li et al. 2002).

The origins of IOD events are unclear. The zonal SST gradient anomaly is significantly correlated with ENSO during the boreal fall (Saji \& Yamagata 2003). This has led to a suggestion that IOD is a part of the ENSO phenomenon (Hendon 2003). However, this seems unlikely for several reasons.

Firstly, though the ENSO correlation is significant, it is moderate and explains only about 20 to $25 \%$ of the variance in the zonal SST gradient time series. Secondly, ENSO and IOD exhibit significantly different spectral behaviour. Based on wavelet analysis of data spanning 40 yr from 1958 to 1997, Saji \& Yamagata (2003) noted the following :

(1) IOD had peak power in the 1960s and 1990s and ENSO in the 1970s and 1980s.

(2) ENSO had a broadband spectrum with continual lengthening of the period from the 1970s till the end of the 1980s; the IOD spectrum exhibited 2 well-separated, elongated and narrow bands.

(3) There was an inverse relation between ENSO and IOD activity on decadal time scales, suggesting that decades of high ENSO activity co-occurred with decades of low IOD activity and vice versa.

Finally, a significant proportion of IOD events occurred independent of ENSO and a significant proportion of ENSO events were independent of IOD. Interestingly, the group of IOD events that occurred in the absence of ENSO accounted for the larger share of variance in Indian Ocean variability than the group that co-occurred with ENSO (Saji \& Yamagata 2003).

An aspect of IOD variability that is relevant to possible hypotheses about its origins is that local coupling of variables within the Indian Ocean is much stronger than their coupling with ENSO. For instance, compare the correlation between equatorial zonal winds and the zonal SST gradient anomaly (correlation $=0.85$ ) and between the latter and ENSO (correlation =0.45) during boreal fall (see Saji \& Yamagata 2003, their Table 1). Another illustration of the relative strength of the local coupling is the association of the zonal SST gradient anomaly with subsurface temperature variability at thermocline depths (correlation $=0.78 ; \mathrm{T}$. Shinoda, $\mathrm{H}$. H. Hendon, M. A. Alexander unpubl.); the correlation of the latter with ENSO is 0.37 (also see Rao et al. 2002).

This strong local coupling suggests an alternate hypothesis that IOD is generated by ocean-atmosphere interactions inherent to the Indian Ocean. The remarkable similarity in the evolution of the zonal SST gradient and the equatorial zonal wind anomaly (Saji et al. 1999) and an equally remarkable similarity in the spectral characteristics of both fields (Saji \& Yamagata 2003) lends empirical support to this hypothesis. In this scenario the correlation between ENSO and IOD is accounted for as mutual interaction, wherein it is speculated that ENSO may trigger IOD sometimes (Xie et al. 2002), that IOD may trigger ENSO at other times (Saji \& Yamagata 2003) and that there are times when the phenomena are uncoupled.

The strength of the local coupling also suggests that IOD may be an important determinant of regional climate fluctuations on interannual timescales. Several recent studies have explored this possibility. For instance, Black et al. (2003) and Clark et al. (2003) have shown that IOD may significantly modulate rain over many African countries during boreal fall and early winter. Ashok et al. (2001; K. Ashok, Z. Guan, N. H. Saji, T. Yamagata unpubl.) have demonstrated that positive IOD events may enhance the summer monsoon rainfall over India. Behera \& Yamagata (2003) suggested that IOD may be a significant modulator of Darwin sea-level pressure in addition to ENSO. Lareef et al. (2003) showed that the fall of 'Maha rains' over Sri Lanka are modulated by IOD.

Regional ocean climate is also significantly affected by IOD. Murtugudde et al. (1999) suggested that IOD events modulate primary productivity off Sumatra and Africa by changing coastal and open-ocean upwelling patterns. Han \& Webster (2002) showed that IOD events strongly influence sea-level variations in the Bay of Bengal. They suggested that through such sea-level anomalies, IOD may have a significant influence on the flooding patterns and associated outbreaks of cholera in Bangladesh (also see Lobitz et al. 2000). Schouten et al. (2002) suggested that IOD may impact the interocean exchange from the Indian to Atlantic oceans.

Thus there is some progress in understanding the possible impacts of IOD events. However, such an understanding is limited to a few regions in the immediate vicinity of the Indian Ocean. Do IOD events impact regions other than the ones mentioned above? 
Especially, do such impacts extend beyond the Indian Ocean? This second question has not been addressed at all. Note that an exception to this statement is the case study of the anomalous East Asian hot summer during 1994 by Guan \& Yamagata (2003). These authors suggested that the anomalous situation resulted from an IOD teleconnection. Nevertheless, it is not know whether other IOD events were associated with similar anomalies.

The purpose of the present study is to explore the possible impacts of IOD events worldwide by searching for systematic correlations with land rainfall and temperature anomalies. It also seeks to understand possible atmospheric mechanisms that may mediate between IOD events and the observed impacts through the analysis of relevant atmospheric variables from a popular atmospheric data assimilation product. The data and methods used in this study will be outlined next.

\section{DATA}

This study analyzed gridded $\left(0.5^{\circ} \times 0.5^{\circ}\right.$ resolution $)$ land rainfall and surface air temperature data of Willmott \& Matsuura (1995), SST data from GISST v2a (Rayner et al. 1996), and reanalyzed (or assimilated) winds and geopotential heights at standard levels from the NCEP Reanalysis project (Kalnay et al. 1996).

The data are monthly means covering a $42 \mathrm{yr}$ period from January 1958 to December 1999. At each grid point, monthly anomalies of each variable were found by subtracting the climatological seasonal cycle from each monthly mean. Subsequently, overlapping 3 mo season anomalies were computed by applying a 3 mo running mean on the anomalies. Linear trends and interdecadal anomalies (defined to be periodicities longer than $7 \mathrm{yr}$ ) were then filtered off from the data for each 3 mo season.

\subsection{Rationale for pre-filtering the data}

The removal of the trend and the interdecadal anomaly were performed for 2 reasons. The climate system is known to exhibit significant interdecadal variability (Nakamura et al. 1997). However, the zonal SST gradient anomaly in the Indian Ocean has negligible trend or interdecadal anomalies (Saji \& Yamagata 2003). Consequently, the presence of the lower frequencies may mask or diminish the associations of IOD with the variables being examined here. This in fact appears to be the case. All the results presented here were also calculated using unfiltered data. Such results are presented whenever possible. It was seen that the filtering only improved the correlations slightly. More importantly, the filtering process did not create any new information. When we do not present the unfiltered results, we have indicated the spatial correlation between filtered and unfiltered results to support the closeness of the structures obtained using both approaches. A second reason for filtering the lower frequency component is that it represents a nonstationary behaviour of the mean. Removing such nonstationarity makes the analyses more consistent with the assumptions upon which correlation analysis is built.

\subsection{Conventions and indices}

In the following, seasons are indicated by combining the first letter of each contiguous month into a single word; thus ASO represents the 3 mo season from August to October. For convenience, adjectives indicating geographic orientation such as south, north, east, etc., are represented by the first letter of the word, e.g., 'S' for south.

The zonal SST gradient anomaly, also referred to as the Dipole Mode Index (DMI; Saji et al. 1999) represents the strength of IOD. The DMI is the SST anomaly difference between the western $\left(60-80^{\circ} \mathrm{E}\right.$, $\left.10^{\circ} \mathrm{S}-10^{\circ} \mathrm{N}\right)$ and eastern $\left(90-110^{\circ} \mathrm{E}, 10^{\circ} \mathrm{S}-\right.$ Equator $)$ Indian Ocean. ENSO is indexed by the familiar Nino3 index and is the average SST anomaly over $5^{\circ} \mathrm{S}-5^{\circ} \mathrm{N}, 150-90^{\circ} \mathrm{W}$.

\section{METHODOLOGY}

We use linear regression and correlation analysis in this study to discuss the possible impacts of IOD. However, as noted above, there is a significant correlation between DMI and Nino3 during the boreal fall. Therefore, it is possible that the linear regression of any variable on DMI would be contaminated to some degree by this correlation.

\subsection{Possible biases due to DMI-Nino3 correlation}

It is illuminating to consider possible biases due to the correlation between DMI and Nino3. Fig. 1a is a composite rain anomaly over part of Africa based on averaging OND rain anomalies during 19 IOD events (see Table 1). Note that the season OND is the second rainfall season in equatorial Africa, the so-called 'short rains' (Zorita \& Tilya 2002).

All the composites discussed here were calculated as follows. First, an average of the concerned variable (in 

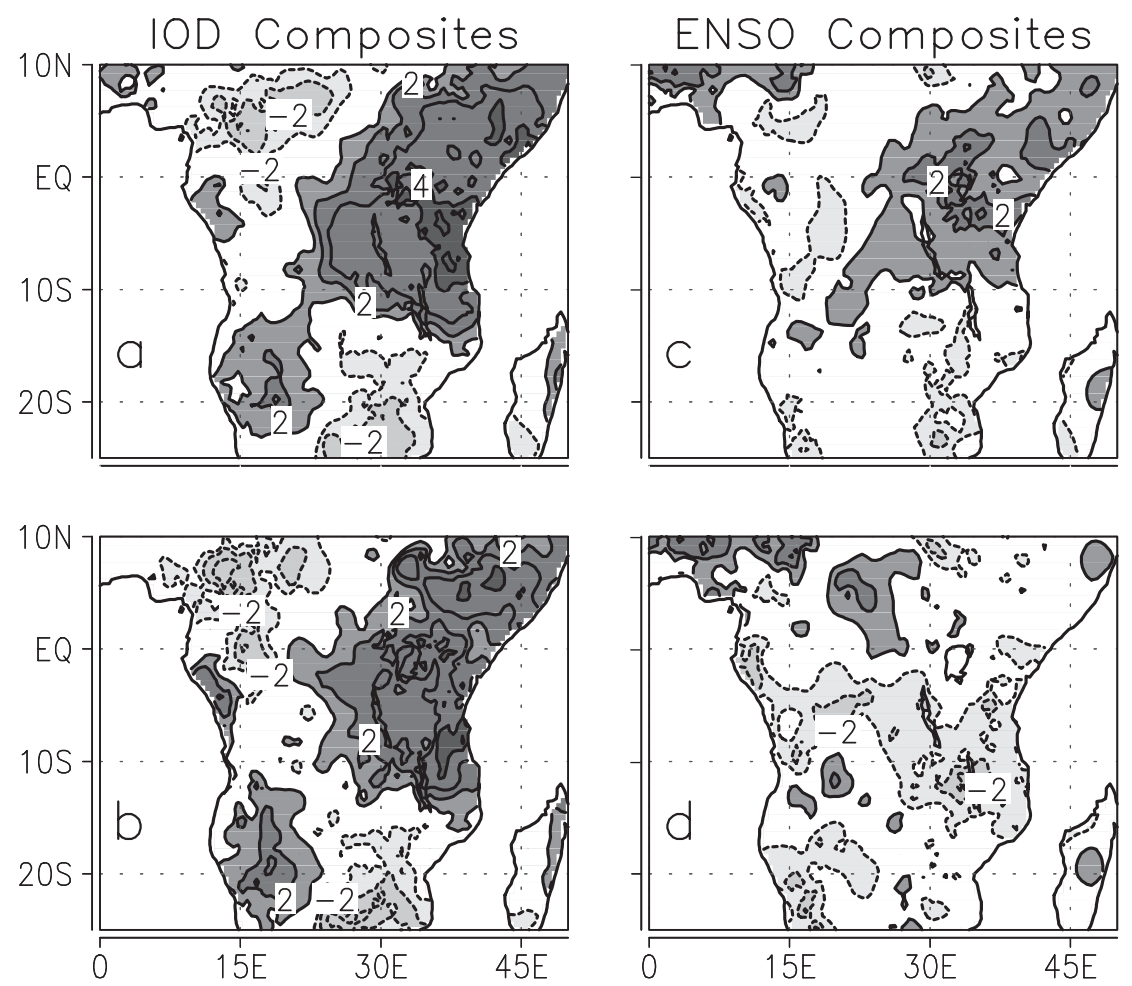

Fig. 1. Composite OND rain anomaly over Africa for (a) 19 IOD events, (b) 11 ENSO-independent IOD events, (c) 20 ENSO events and (d) 12 IOD-independent ENSO events. The composite anomaly was normalized by the standard deviation of rain during OND. Contours given at $\pm 1, \pm 2$, etc.

this example, rain anomaly) was found for all positive IOD events. Next, an average was calculated for negative IOD events. The difference between these composites was calculated and divided by 2 . Similarly for ENSO composites.

Table 1. Years of IOD and ENSO used in the study. Independent IOD and ENSO events and co-occurring IOD-ENSO events are given

\begin{tabular}{|c|c|c|c|}
\hline Positive IOD & El Niño & Negative IOD & La Niña \\
\hline \multicolumn{4}{|c|}{ Independent IOD and ENSO events } \\
\hline 1961 & 1965 & 1958 & 1967 \\
\hline $1967^{\mathrm{a}}$ & 1969 & 1960 & 1970 \\
\hline 1977 & 1976 & 1974 & 1973 \\
\hline 1983 & 1986 & 1989 & 1978 \\
\hline \multirow[t]{3}{*}{1994} & 1987 & 1992 & 1984 \\
\hline & & 1993 & 1985 \\
\hline & & & 1988 \\
\hline \multicolumn{4}{|c|}{ Co-occurring IOD-ENSO events } \\
\hline 1963 & 1963 & 1964 & 1964 \\
\hline 1972 & 1972 & 1971 & 1971 \\
\hline 1982 & 1982 & 1975 & 1975 \\
\hline 1997 & 1997 & 1996 & 1996 \\
\hline
\end{tabular}

Fig. $1 \mathrm{~b}$ is the composite map for 11 of the IOD events that were independent of ENSO (Table 1). The composite rain anomaly for 20 ENSO events is shown in Fig. 1c. In Fig. 1d, however, the composite is for 12 of the ENSO events that were independent of IOD. All the ENSO and IOD events used for forming the composites were identified using criteria described by Saji \& Yamagata (2003).

Fig. 1c may suggest that ENSO events lead to fluctuations of the 'short rains'. This appears to be a well-accepted hypothesis (Mutai \& Ward 2000), despite the existence of modelling studies that contradict it (for example, Goddard \& Graham 1999). However, it is seen that this is an apparent effect arising from IOD events co-occurring with it. Once the co-occurring IOD and ENSO events are removed from the analysis as in Fig. 1d, it is clear that ENSO apparently has little to do with African rain variability during OND. On the other hand, IOD is consistently associated with African rain variability during OND, whether or not it co-occurs with ENSO.

A second type of bias is illustrated in Fig. 2. Fig. 2 is similar to Fig. 1, except that the composites are for JJAS land surface temperature anomaly over NE Asia. Note that positive IOD (ENSO) events are associated with warm (cold) surface temperature anomalies. During a cooccurring IOD-ENSO event, these tendencies apparently negate each other, thereby explaining the relative weak amplitudes in Fig. 2a,c, compared to Fig. 2b,d.

Biases as illustrated above are well known and documented in the statistical-analysis literature. Interested readers will find more information in Panofsky \& Brier (1958) and Cohen \& Cohen (1983).

In theory, it is impossible to avoid such biases from affecting inferences based on statistical analysis. Thus a left-out unknown variable may be the true cause of an effect ascribed to other causal variables, or it may suppress the true effect of causal variables. This is to be kept in mind in interpreting the current analysis. Having said that, we proceed to the assumptions of this study.

\subsection{Assumptions}

The first assumption is that the redundancy with ENSO alone needs to be taken into account in searching for IOD teleconnections. The assumption may be justi- 

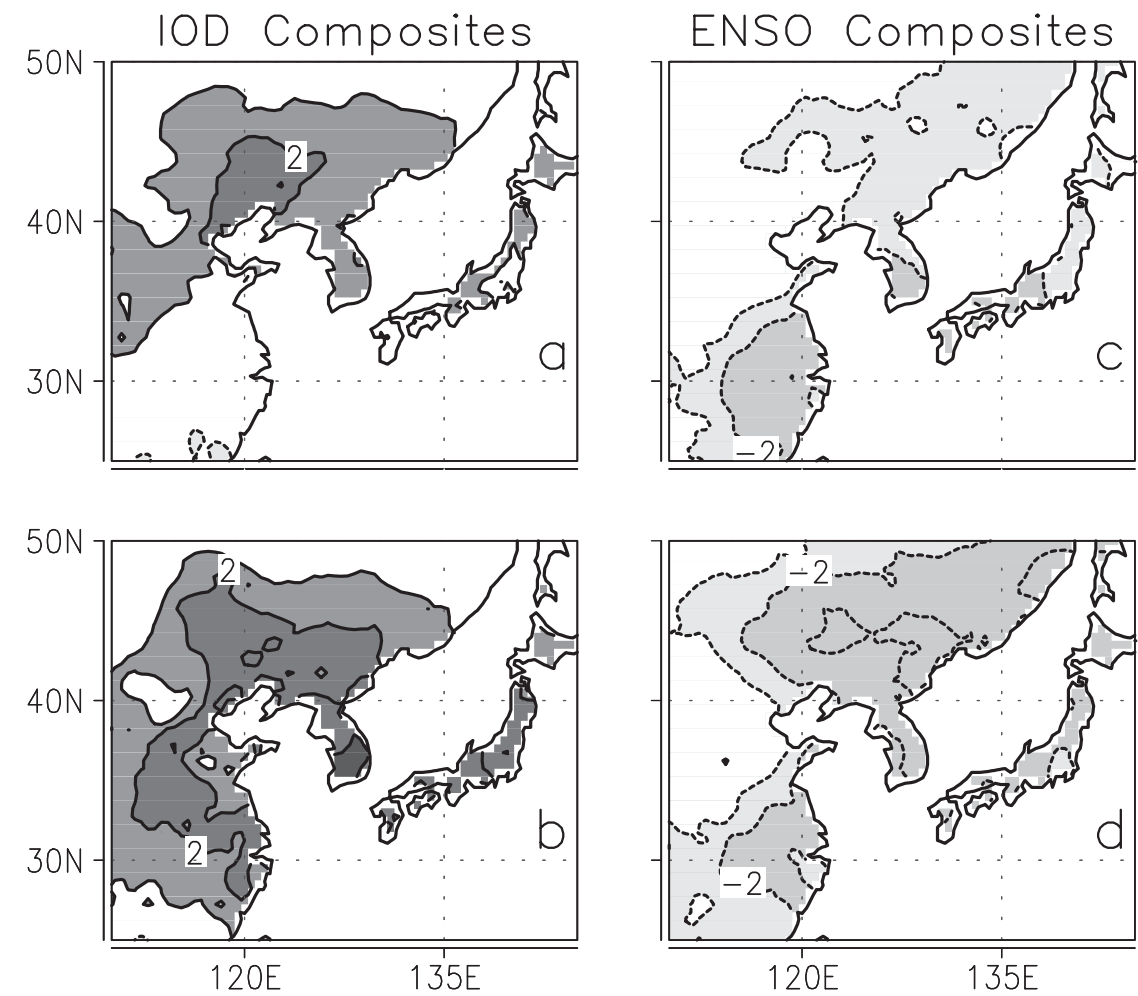

Fig. 2. Composite surface temperature anomaly over NE Asia during JJAS for (a) 19 IOD events, (b) 11 ENSO-independent IOD events, (c) 20 ENSO events and (d) 12 IOD-independent ENSO events. The composite anomaly was normalized by the standard deviation of rain during OND. Contours given at $\pm 1, \pm 2$, etc. wards. Though the Indian Ocean occupies only half as much area as the Pacific in the near equatorial regions, the summed variance over the former is nearly $60 \%$ of that in the latter. Thus, the Indian Ocean is associated with more rain variance and therefore more latent heat release than the Pacific. In contrast, the contribution by the Atlantic is only $20 \%$ or less of that in the Pacific. Therefore, even if IOD may share some unknown redundancy with tropical Atlantic phenomena, the biases due to that may be negligible.

The second important assumption is that IOD and ENSO are independent phenomena with unique causative mechanisms. In particular we assume that IOD is not an effect of ENSO. This implies that both phenomena have a sufficient degree of independence, i.e. they occur independently for a sufficient fraction of the time. As apparent from the numbers presented in Section 1, and from studies such as that of Feng \& Meyers (2003), Rao et al. (2002), Saji \& Yamagata (2003), and T. Shinoda, H. H. Hendon, M. A. Alexander (unpubl.), this is a reasonable assumption. fied to some extent. First, it is currently not known if IOD is strongly correlated with any other tropical ocean-atmosphere phenomenon than the ENSO. Second, convective variability in the equatorial Indian Ocean is nearly as strong as that in the Pacific. However, the convective variability in the Atlantic is much weaker than either of the former. This is illustrated using Fig. 3. The data used for these calculations is described in Xie \& Arkin (1996). This data merges available observations with satellite estimates and is available from 1979 on-

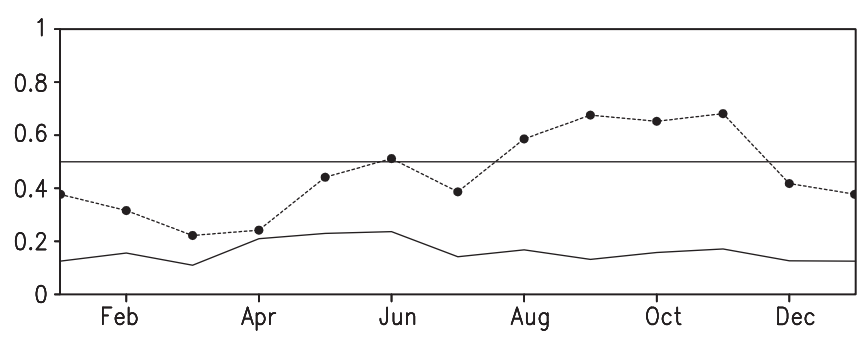

Fig. 3. Ratio of interannual rain variance over the equatorial Indian Ocean $\left(40-120^{\circ} \mathrm{E}, 10^{\circ} \mathrm{S}-10^{\circ} \mathrm{N}\right)$ to that over the equatorial Pacific $\left(120^{\circ} \mathrm{E}-80^{\circ} \mathrm{W}, 10^{\circ} \mathrm{S}-10^{\circ} \mathrm{N}\right)$ (points and dotted line). Solid line: ratio of the same quantity over the equatorial Atlantic $\left(80^{\circ} \mathrm{W}-0^{\circ}, 10^{\circ} \mathrm{S}-10^{\circ} \mathrm{N}\right)$ to that over the equatorial Pacific

\subsection{Partial correlations}

In this study, we use partial correlations to document the possible impacts of IOD. The definition of the partial correlation follows:

$$
p r_{1}=\frac{r_{Y 1}-r_{Y 2} r_{12}}{\sqrt{\left(1-r_{12}^{2}\right)\left(1-r_{Y 2}^{2}\right)}}
$$

where $r_{Y 1}$ is the simple correlation of the dependent variable, $Y$, and the causative variable $X_{1}$ (say Nino3). Similarly, $r_{Y 2}$ is the simple correlation between $Y$ and $X_{2}$ (say DMI), and $r_{12}$ that between $X_{1}$ and $X_{2}$.

$p r_{1}$ is the correlation between $Y$ from which $X_{2}$ has been partialled and $X_{1}$ from which $X_{2}$ has been partialled. The square of the quantity, $p r_{1}{ }^{2}$, answers the question of how much of the $Y$ variance that is not estimated by $X_{2}$ in the equation is estimated by $X_{1}$.

Throughout the analysis, SON values of DMI and Nino3 are correlated against seasonal values of the variables presented here. We do this in order to capture the seasonally changing structure in the association between IOD (ENSO) and the variables presented in this study. Local significance of the results are estimated based on a 2-tailed Student's $t$-test (Cohen \& 
Cohen 1983). In the following, we use $p r_{\mathrm{d}}\left(p r_{\mathrm{n}}\right)$ to indicate the partial correlation of a variable on DMI (Nino3), partialling Nino3 (DMI).

\section{RESULTS}

The partial correlation of land temperature (and rain) anomalies on SON DMI independent of SON Nino3 was calculated and mapped for JJA and SON (not shown, but see Fig. 21). Prior to this calculation, we subjected the land temperature and rain anomaly at each grid to a 9-point spatial smoothing. The result of the smoothing at each grid is a weighted average of the grid point plus the 8 surrounding points. The center point receives a weight of 1.0, the points at each side and above and below receive a weight of 0.5 , and corner points receive a weight of 0.3 . The smoothing was performed to reduce the spatial noise in the high spatial resolution data. However, it has no significant effect on the results presented here, as the focus is on larger-scale patterns and interannual timescales.

From the above maps, we located regions where DMI had correlations with rain and temperature anomalies that were significant at the $95 \%$ significance level or higher. Area-averaged standardized anomalies over such regions were calculated, and a 3 mo running mean applied to form a time series of overlapping 3 mo seasons. The partial correlation of SON DMI with each season of this timeseries independent of Nino3 was found and tabulated in Tables $2 \& 3$.

The above procedure does not protect against picking and choosing areas or season combinations where a test happens to be significant. It is quite possible that a particular seasonal combination over a certain area may have shown significance just by chance. To guard against such chance events we performed, in addition to the local $t$-test, a field significance test as discussed by Livezey \& Chen (1983). The field significance
Table 2. Association of land temperature over selected regions with DMI and Nino3. $p_{\mathrm{d}}\left(p_{\mathrm{n}}\right)$ is the correlation of temperature on DMI (Nino3), partialling the effects of Nino3(DMI); values in parenthesis are correlations using unfiltered data. Season: the season of largest association with DMI. Eq: equator

\begin{tabular}{|llcc|}
\hline Region & Season & $p_{\mathrm{d}}$ & $p_{\mathrm{n}}$ \\
\hline South Africa $\left(15-25^{\circ} \mathrm{E}, 35-20^{\circ} \mathrm{S}\right)$ & $\mathrm{SON}$ & $+0.49(+0.43)$ & $-0.04(-0.09)$ \\
E Africa $\left(25-45^{\circ} \mathrm{E}, 10^{\circ} \mathrm{S}-\mathrm{Eq}.\right)$ & $\mathrm{JJA}$ & $+0.49(+0.39)$ & $-0.28(-0.14)$ \\
SE Europe $\left(0-15^{\circ} \mathrm{E}, 30-40^{\circ} \mathrm{N}\right)$ & $\mathrm{JJA}$ & $+0.45(+0.36)$ & $-0.22(-0.14)$ \\
$\mathrm{S}$ Iran $\left(55-65^{\circ} \mathrm{E}, 25-35^{\circ} \mathrm{N}\right)$ & $\mathrm{SON}$ & $+0.45(+0.30)$ & $-0.21(-0.05)$ \\
NE Asia $\left(115-150^{\circ} \mathrm{E}, 39-45^{\circ} \mathrm{N}\right)$ & $\mathrm{JJA}$ & $+0.55(+0.51)$ & $-0.40(-0.31)$ \\
Papua New Guinea $\left(135-150^{\circ} \mathrm{E}, 10-\mathrm{Eq}.\right)$ & $\mathrm{SON}$ & $-0.53(-0.38)$ & $-0.13(-0.07)$ \\
$\mathrm{N}$ Australia $\left(122-136^{\circ} \mathrm{E}, 21-15^{\circ} \mathrm{S}\right)$ & $\mathrm{JJA}$ & $-0.51(-0.39)$ & $+0.00(+0.03)$ \\
SW Australia $\left(115-150^{\circ} \mathrm{E}, 40-25^{\circ} \mathrm{S}\right)$ & $\mathrm{SON}$ & $+0.58(+0.51)$ & $-0.19(-0.08)$ \\
North America $\left(72-54^{\circ} \mathrm{W}, 42-53^{\circ} \mathrm{N}\right)$ & $\mathrm{JAS}$ & $+0.57(+0.34)$ & $-0.71(-0.54)$ \\
South America $\left(70-40^{\circ} \mathrm{W}, 30-10^{\circ} \mathrm{S}\right)$ & $\mathrm{ASO}$ & $+0.73(+0.67)$ & $-0.26(-0.22)$ \\
\hline
\end{tabular}

Table 3. Association of land rain over selected regions with DMI and Nino3. $p_{\mathrm{d}}\left(p_{\mathrm{n}}\right)$ is the correlation of temperature on DMI (Nino3), partialling the effects of Nino3 (DMI); values in parentheses are correlations using unfiltered data. Season: the season of largest association with DMI

\begin{tabular}{|c|c|c|c|}
\hline Region & Season & $p_{\mathrm{d}}$ & $p_{\mathrm{n}}$ \\
\hline South Africa $\left(20-30^{\circ} \mathrm{E}, 35-32^{\circ} \mathrm{S}\right)$ & SON & $-0.50(-0.30)$ & $+0.30(+0.20)$ \\
\hline Angola $\left(10-20^{\circ} \mathrm{E}, 20^{\circ} \mathrm{S}-10^{\circ} \mathrm{N}\right)$ & OND & $+0.49(+0.33)$ & $-0.32(-0.27)$ \\
\hline Gabon $\left(9-12^{\circ} \mathrm{E}, 6^{\circ} \mathrm{S}-2^{\circ} \mathrm{N}\right)$ & OND & $+0.50(-0.36)$ & $-0.45(+0.39)$ \\
\hline Djibouti $\left(41-44^{\circ} \mathrm{E}, 11-13^{\circ} \mathrm{N}\right)$ & SON & $+0.52(+0.44)$ & $-0.10(-0.06)$ \\
\hline Ethiopia $\left(32-46^{\circ} \mathrm{E}, 3-7^{\circ} \mathrm{N}\right)$ & SON & $+0.60(+0.51)$ & $-0.17(-0.10)$ \\
\hline Somalia $\left(41-46^{\circ} \mathrm{E}, 0-5^{\circ} \mathrm{N}\right)$ & SON & $+0.60(+0.56)$ & $+0.11(+0.11)$ \\
\hline Uganda $\left(29-35^{\circ} \mathrm{E}, 1^{\circ} \mathrm{S}-4^{\circ} \mathrm{N}\right)$ & $\mathrm{SON}$ & $+0.53(+0.50)$ & $-0.32(-0.30)$ \\
\hline $\begin{array}{l}\text { Democratic Republic of Congo } \\
\left(24-30^{\circ} \mathrm{E}, 10-2^{\circ} \mathrm{S}\right)\end{array}$ & & & \\
\hline Tanzania $\left(30-40^{\circ} \mathrm{E}, 10-2^{\circ} \mathrm{S}\right)$ & SON & $+0.67(+0.64)$ & $-0.02(+0.03)$ \\
\hline N Mozambique $\left(35-40^{\circ} \mathrm{E}, 14-10^{\circ} \mathrm{S}\right)$ & SON & $+0.42(+0.31)$ & $-0.02(+0.04)$ \\
\hline S Germany $\left(8-15^{\circ} \mathrm{E}, 46-51^{\circ} \mathrm{N}\right)$ & ASO & $-0.52(-0.46)$ & $+0.05(+0.09)$ \\
\hline Hungary $\left(17-23^{\circ} \mathrm{E}, 44-48^{\circ} \mathrm{N}\right)$ & SON & $-0.44(-0.38)$ & $+0.13(+0.16)$ \\
\hline Ukraine $\left(24-34^{\circ} \mathrm{E}, 46-52^{\circ} \mathrm{N}\right)$ & $\mathrm{SON}$ & $-0.53(0.51)$ & $+0.26(+0.26)$ \\
\hline Egypt $\left(29-34^{\circ} \mathrm{E}, 26-31^{\circ} \mathrm{N}\right)$ & SON & $+0.51(+0.50)$ & $+0.15(+0.13)$ \\
\hline S Pakistan $\left(65-69^{\circ} \mathrm{E}, 24-27^{\circ} \mathrm{N}\right)$ & JAS & $+0.46(+0.40)$ & $-0.46(-0.43)$ \\
\hline NW India $\left(75-80^{\circ} \mathrm{E}, 20-26^{\circ} \mathrm{N}\right)$ & OND & $+0.53(+0.33)$ & $-0.12(+0.02)$ \\
\hline Bhutan $\left(89-92^{\circ} \mathrm{E}, 27-28^{\circ} \mathrm{N}\right)$ & JJA & $-0.53(-0.32)$ & $+0.09(-0.09)$ \\
\hline Lhasa $\left(89-94^{\circ} \mathrm{E}, 28-30^{\circ} \mathrm{N}\right)$ & JJA & $-0.47(-0.33)$ & $+0.05(+0.03)$ \\
\hline S China $\left(105-112^{\circ} \mathrm{E}, 25-29^{\circ} \mathrm{N}\right)$ & SON & $+0.58(+0.51)$ & $+0.22(+0.18)$ \\
\hline Sri Lanka $\left(80-82^{\circ} \mathrm{E}, 6-8^{\circ} \mathrm{N}\right)$ & SON & $+0.49(+0.48)$ & $+0.14(+0.16)$ \\
\hline S Sumatra $\left(100-106^{\circ} \mathrm{E}, 6^{\circ} \mathrm{S}-\mathrm{Eq}.\right)$ & JAS & $-0.80(-0.75)$ & $-0.19(-0.12)$ \\
\hline Java $\left(106-115^{\circ} \mathrm{E}, 8.5-6^{\circ} \mathrm{S}\right)$ & $\mathrm{SON}$ & $-0.65(-0.56)$ & $-0.33(-0.27)$ \\
\hline Kalimantan $\left(110-118^{\circ} \mathrm{E}, 4^{\circ} \mathrm{S}-5^{\circ} \mathrm{N}\right)$ & SON & $-0.55(-0.48)$ & $-0.50(-0.43)$ \\
\hline Sulawesi $\left(119-123^{\circ} \mathrm{E}, 6-1^{\circ} \mathrm{S}\right)$ & ASO & $-0.52(-0.40)$ & $-0.62(-0.51)$ \\
\hline New Guinea $\left(134-14 \& 1^{\circ} \mathrm{E}, 10-2^{\circ} \mathrm{S}\right)$ & JAS & $+0.10(+0.15)$ & $-0.71(-0.71)$ \\
\hline SW Australia $\left(115-130^{\circ} \mathrm{E}, 34-20^{\circ} \mathrm{S}\right)$ & JJA & $-0.58(-0.58)$ & $+0.24(+0.25)$ \\
\hline Central America $\left(97-87^{\circ} \mathrm{W}, 14-19^{\circ} \mathrm{N}\right)$ & OND & $-0.39(-0.35)$ & $+0.12(+0.10)$ \\
\hline W USA $\left(112-106^{\circ} \mathrm{W}, 35-39^{\circ} \mathrm{N}\right)$ & ASO & $+0.46(+0.39)$ & $-0.16(-0.13)$ \\
\hline Quebec $\left(80-74^{\circ} \mathrm{W}, 49-53^{\circ} \mathrm{N}\right)$ & JJA & $-0.54(-0.40)$ & $+0.33(+0.07)$ \\
\hline Venezuela $\left(66-63^{\circ} \mathrm{W}, 5-10^{\circ} \mathrm{N}\right)$ & ASO & $+0.65(+0.61)$ & $-0.72(-0.68)$ \\
\hline S Brazil $\left(70-50^{\circ} \mathrm{W}, 25-15^{\circ} \mathrm{S}\right)$ & ASO & $-0.57(-0.61)$ & $+0.52(0.55)$ \\
\hline Uruguay $\left(57-52^{\circ} \mathrm{W}, 34-31^{\circ} \mathrm{S}\right)$ & JJA & $+0.55(0.42)$ & $-0.23(-0.16)$ \\
\hline S Chile $\left(72-70^{\circ} \mathrm{W}, 36-33^{\circ} \mathrm{S}\right)$ & ASO & $+0.52(+0.41)$ & $+0.37(+0.33)$ \\
\hline S Argentina $\left(70-66^{\circ} \mathrm{W}, 45-41^{\circ} \mathrm{S}\right)$ & JJA & $+0.46(+0.42)$ & $+0.08(+0.11)$ \\
\hline
\end{tabular}


test is performed separately for all of the regions identified according to the procedure described in the previous paragraph. In addition to the spatial field, the test also considers all the seasons in a single test.

A Monte Carlo procedure was adapted to estimate significance levels. The DMI timeseries was shuffled in random order without any replacement. The Nino3 timeseries was then shuffled in the same order as the DMI, so as to preserve the correlation between the two. The shuffled index time series are then correlated with the rain or temperature field over a prescribed region over both space and time according to Eq. (1). Then the percentage of space-time points above the $95 \%$ local significance level is calculated. The procedure is repeated 10000 times. From this the number of space-time points that would equal $5 \%$ by chance is calculated and used as the criteria that the space-time points in the observed correlations with the real DMI and Nino3 time series should pass. Tables $2 \& 3$ reports only those regions that have passed this field significance test.

\subsection{Land surface temperature}

Table 2 tabulates 10 regions where land temperature anomaly was significantly correlated with DMI (i.e. passed the local and field significance test at the $95 \%$ level). To compare with the influence of ENSO over these regions, we also noted the partial correlation of temperature on Nino3, independent of DMI. To demonstrate that the filtering of the linear trend and the decadal anomaly does not have a significant effect on the results, we have also tabulated the correlations using unfiltered data.

It is rather surprising that a number of regions remote from the Indian Ocean show large correlations with DMI. Such a region is subtropical South America, where interestingly the correlation with DMI is the largest among all the tabulated regions $\left(p r_{d}=+0.73\right)$. Examination of the anomaly time series (not shown) suggests that IOD is consistently associated with warm anomalies during positive events and cool anomalies during negative events. Other remote regions where IOD appears to have a significant influence are NE Asia, North America, SE Europe, S Iran, South Africa and SW Australia. It is interesting that the correlations of IOD with extratropical regions are all positive.

The pattern of temperature anomaly over tropical land regions in the immediate vicinity of the Indian Ocean is as expected. Regions close to the eastern Indian Ocean (Papua New Guinea, N Australia) have negative correlations, while regions near the western basin (E Africa) have positive correlations.
Most of the regions ( 7 out of 10 ) were insignificantly correlated with Nino3, implying that IOD may be an important factor for interannual variations over these regions. Over the rest (E Africa, NE Asia, N America), land temperature showed positive correlation with DMI and negative correlation with Nino3.

\subsection{Land rain anomaly}

Table 3 was constructed similarly to Table 2, except that the results are for land rain anomalies. Figs. 4-9 additionally show how the partial correlations evolve with season over these regions.

Appreciating the regional scale of rainfall characteristics, we have presented our results on rainfall on much smaller spatial scales compared to our results on temperature. We have tried to be more precise in naming the regions in Table 3. In most of Table 3 and Figs. 4-9, a region is identified by name of country and the relative position of the region within the country. In some cases, the rainfall anomaly falls over more than one country. In these cases we have used the name of the country over which a majority of the anomaly falls. In other cases, when a small part of a particular country was affected or when regions within a country was separated by sea, we have used the name of the particular province/state where the rain anomaly fell to identify the region.

Over the tropical regions surrounding the Indian Ocean, the observed associations are aligned in an expected manner. Previous studies (Behera et al. 1999, Saji et al. 1999) have suggested that rain is anomalously decreased over the eastern half of the Indian Ocean and increased over the western half during positive IOD events. The results of Table 3 are well in agreement with this (see also Figs. 4 \& 7).

Overall in regions surrounding the Indian Ocean, IOD appears to contribute strongly to rain variability. For example, $p r_{\mathrm{d}}^{2}\left(p r_{\mathrm{d}}\right.$ is the partial correlation of rain with DMI, partialling Nino3) indicates that DMI is associated with $36 \%$ of the variance over SW Australia, $64 \%$ over Sumatra and $45 \%$ over Tanzania. More interesting is the fact that over many of these regions ENSO loses its supposed association with rain once DMI is factored in.

However, there are some regions where DMI and Nino3 have opposing correlations with the same rain anomaly. Over Pakistan, for instance, DMI is positively correlated with rain and opposes the negative association with Nino3. As Ashok et al. (2001) have suggested, this opposition of influences may explain the loss of coupling between ENSO and the Indian Monsoon at times when ENSO co-occurs with IOD (for example, 1997). 

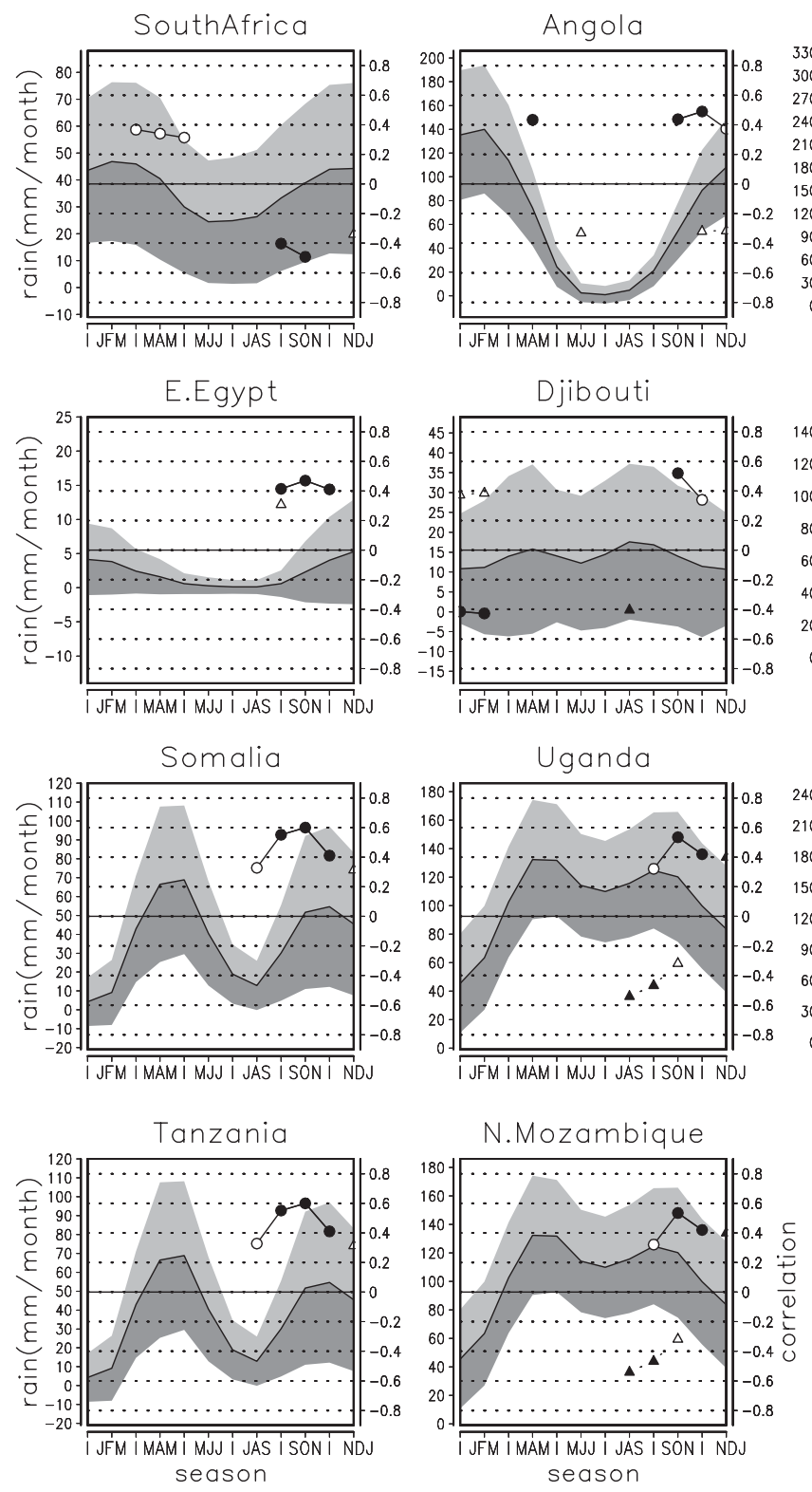
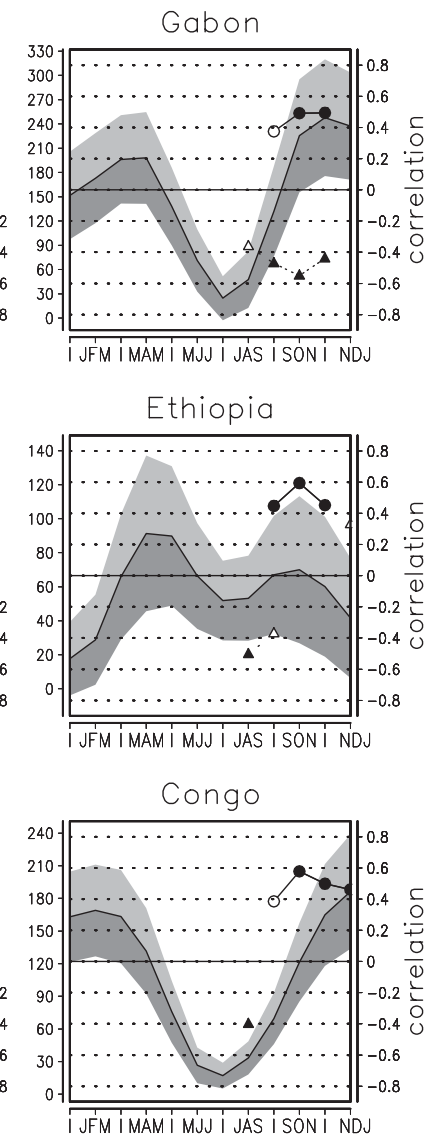

Fig. 4. Temporal evolution of the partial correlation of rain anomalies over various African regions (see Table 3 for precise definition) on DMI independent of Nino3 at the 95 (99)\% [open (solid) circles], and that of rain on Nino3, independent of DMI at the 95 (99)\% level [open (solid) triangles]. Black line: annual cycle of rain over the region; grey lines: $\pm 1 \mathrm{SD}$ of the interannual variability
Over the extratropical regions, it was earlier noted that DMI was positively correlated with temperature. On the other hand DMI is negatively correlated with rain over the same regions. It is also noted that over the extratropics the correlations of DMI and Nino3 (with both temperature and rain) oppose each other.

Rain anomalies over the maritime continent exhibit an interesting pattern. From Fig. 7, it can be seen that
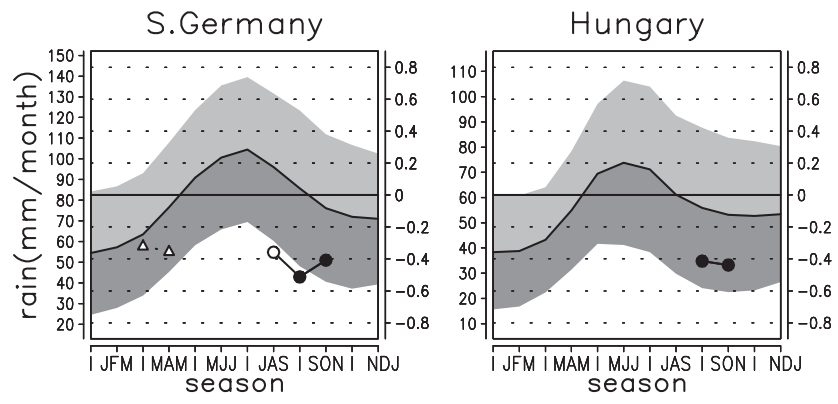

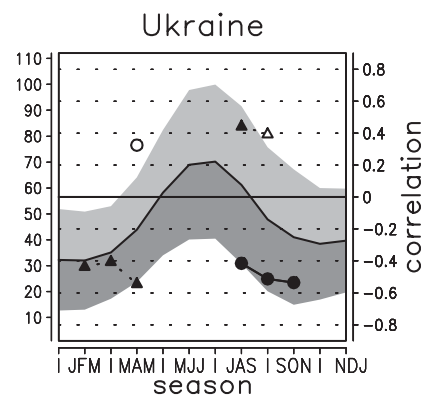

Fig. 5. Temporal evolution of the partial correlation of rain anomalies over Europe. Details as in Fig. 4 

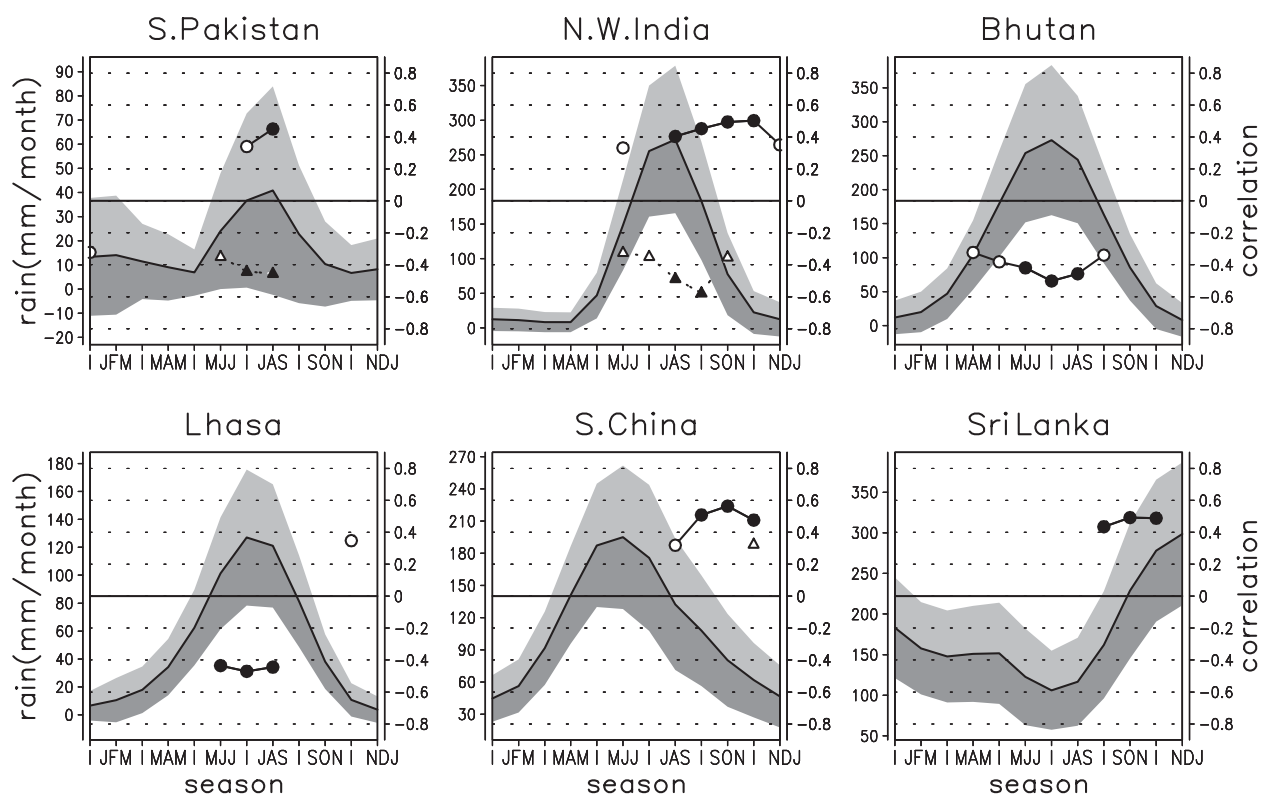

Fig. 6. Temporal evolution of the partial correlation of rain anomalies over Asia. Details as in Fig. 4

the rain anomaly is more strongly associated with DMI over the western half of the region (say Kalimantan), while over the eastern half the correlation is much stronger with Nino3. For example, $p r_{\mathrm{d}}$ is -0.8 over Sumatra while $p r_{\mathrm{n}}$ is -0.19 . Over Kalimantan/Sulawesi, however, $p r_{\mathrm{d}}$ is $-0.55 /-0.52$ and $p r_{\mathrm{n}}$ is $-0.50 /-0.62$. To the east of these regions, for example, Papua New Guinea, DMI has insignificant correlation $\left(p r_{\mathrm{d}}=0.1\right)$ while Nino3 has a significant strong correlation $\left(p r_{\mathrm{n}}=\right.$ $-0.71)$.

\subsection{Tropical atmospheric variability}

Likely the observed anomalies in land rain and temperature have their counterparts in atmospheric variability. This was investigated next, starting from the tropics.

In the tropics, it was found that the largest associations of IOD with atmospheric variability was in the vicinity of the Indian Ocean. As we will show, the structure of the variability can be discussed largely in terms of zonal and meridional overturning cells.
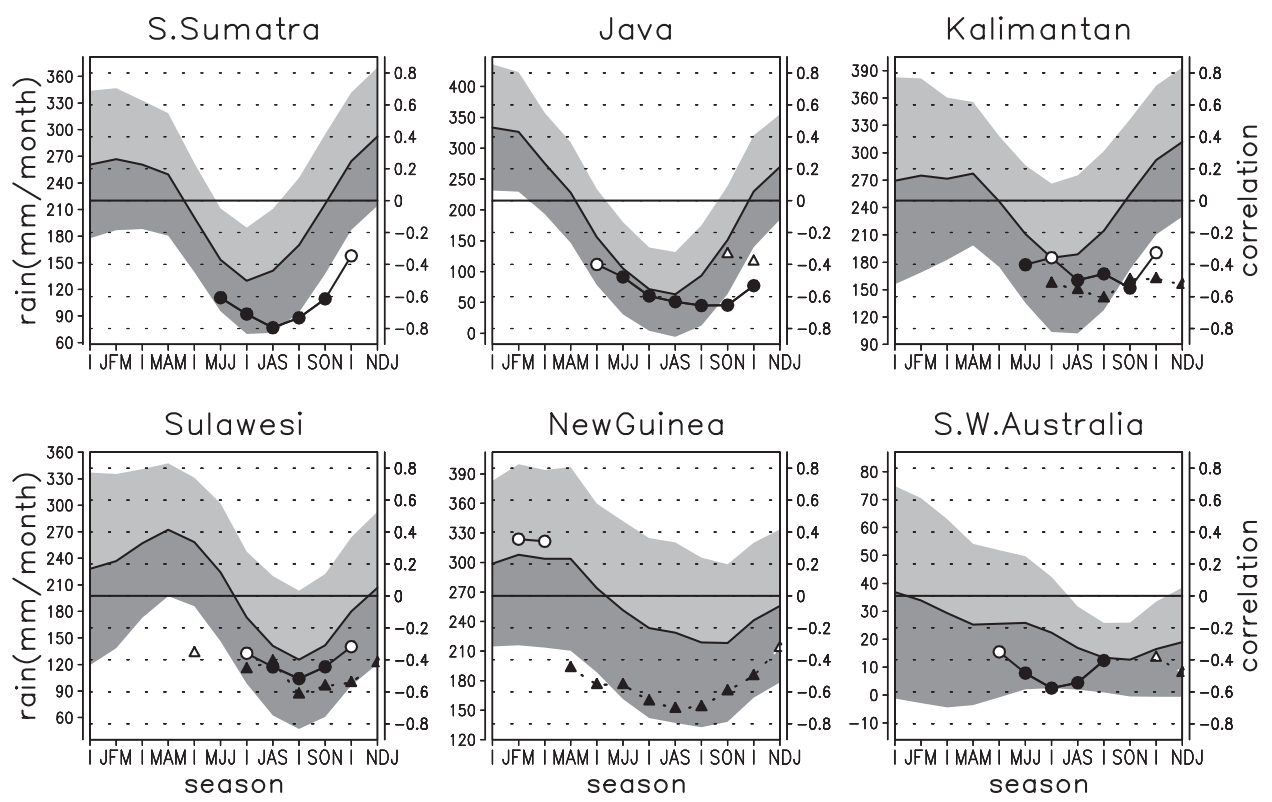

Fig. 7. Temporal evolution of the partial correlation of rain anomalies over the Maritime continent. Details as in Fig. 4 

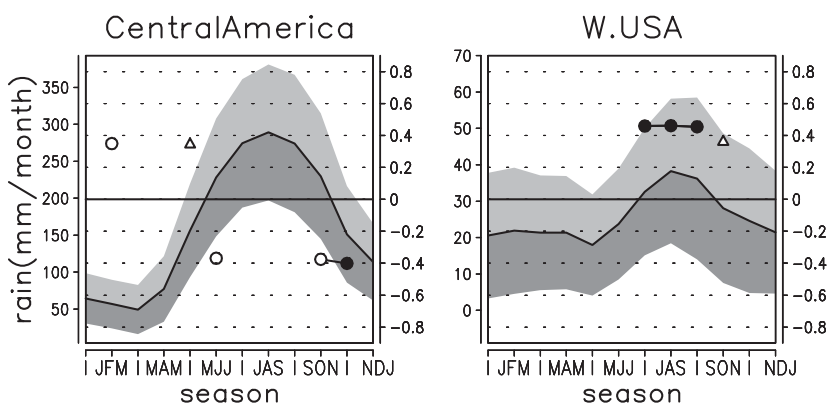

Previous studies (see Section 1) have shown that the equatorial zonal surface wind anomaly is strongly coupled to the large-scale oceanic variability representative of IOD events. Here we expand on this relation by examining the vertical structure and seasonal evolution of the zonal wind anomalies in the central equatorial Indian Ocean. An equatorial zonal wind anomaly at $90^{\circ} \mathrm{E}$ was calculated as an average anomaly between $5^{\circ} \mathrm{S}$ and $5^{\circ} \mathrm{N}$ for different atmospheric levels and seasons. The partial correlation of this time series on DMI (Nino3) independent of Nino3 (DMI) is shown in Fig. 10a(b). Consistent with other studies (Saji et al. 1999, Saji \& Yamagata 2003), the surface wind anomaly is significantly correlated with DMI from boreal spring until early winter. The strongest easterly anomaly associated with DMI $(\mathrm{r}=-0.9)$ is found during ASO at $925 \mathrm{mb}$. The strongest westerly anomaly associated with DMI ( $\mathrm{r}=+0.7$ ) occurs at $200 \mathrm{mb}$ during SON. The vertical structure of the wind anomaly is baroclinic (Fig. 10a), indicating that during positive IOD events, the surface easterly anomalies are overlain by westerlies in the upper troposphere. Note that this structure is in good agreement with the expected tropical atmo-

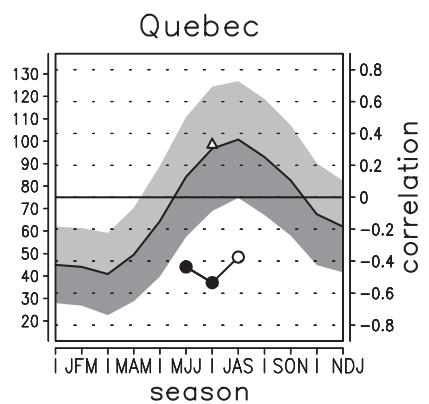

Fig. 8. Temporal evolution of the partial correlation of rain anomalies over the North American continent. Details as in Fig. 4

spheric response to underlying SST anomalies (Matsuno 1966, Gill 1980).

At this location over the Indian Ocean, Nino3 has little or weak correlation with the wind variability at any level. In the boreal winter months, however, Nino3 is associated with easterly wind anomaly in the surface and westerly wind anomaly at around $150 \mathrm{mb}$ (Fig. 10b).

The baroclinic structure of the zonal wind anomaly is suggestive of a zonal overturning (or 'Walker') cell in the equatorial Indian Ocean. To clarify this, Fig. 11 shows the longitude-height cross section of the partial correlations during ASO. To qualitatively visualize the cell, we have superimposed the partial regression coefficients of zonal and vertical wind anomalies as vectors. Fig. 11a,b depict 2 individual, localized anomalous 'Walker' cells, one over the equatorial Indian in association with DMI, and the other over the Pacific in association with Nino3. The Indian Ocean cell spans the entire equatorial Indian Ocean, with rising motion off Africa and sinking motion off Indonesia during positive IOD events, and supports the schematic picture proposed by Webster et al. (1999).
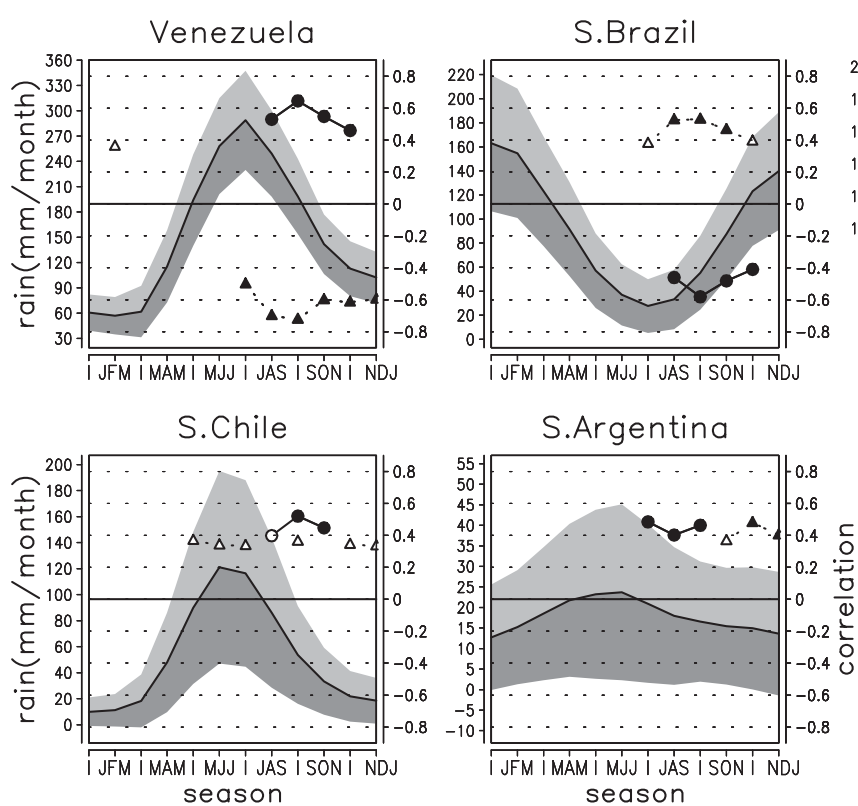

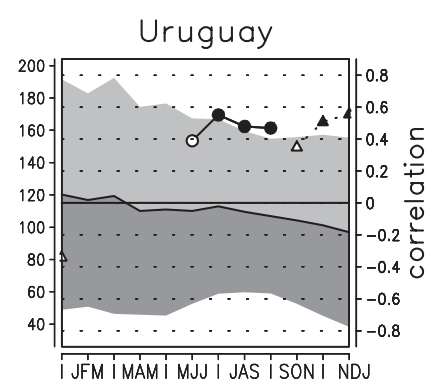

Fig. 9. Temporal evolution of the partial correlation of rain anomalies over the South American continent. Details as in Fig. 4 
a) $10 D$-zonal wind $90^{\circ} \mathrm{E}$

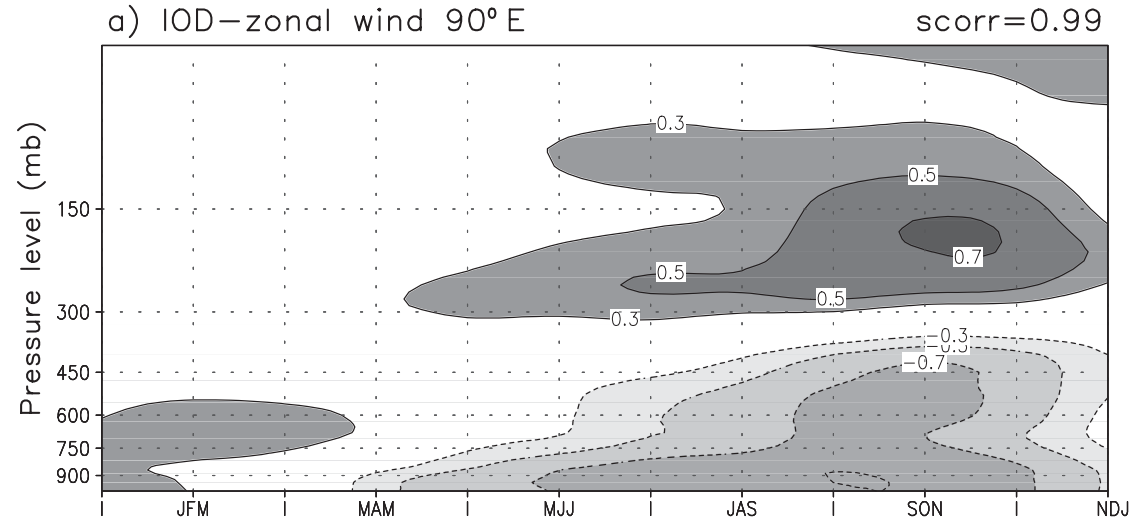

b) ENSO-zonal wind $90^{\circ} \mathrm{E}$

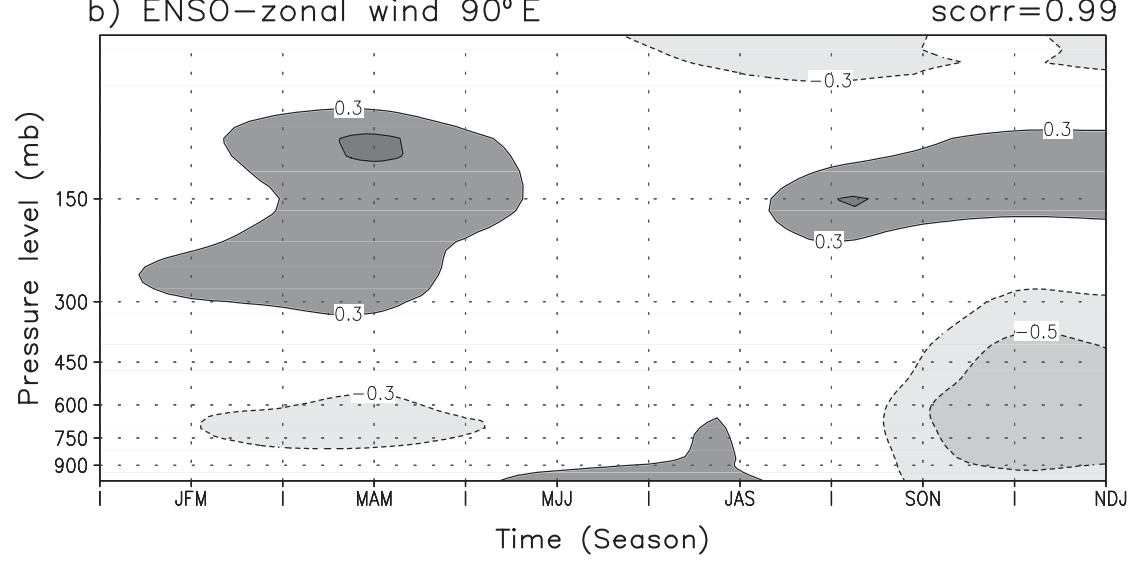

Fig. 10. Partial correlation of equatorial zonal wind anomaly (a) on DMI independent of Nino3 and (b) on Nino3 independent of DMI, as a function of atmospheric level and season. Correlations significant at and above the $95 \%$ level $(\mathrm{r}= \pm 0.3)$ are presented. scorr: spatial correlation coefficient between structures obtained using unfiltered and filtered (detrended) data

The Pacific cell likewise spans the equatorial Pacific with rising motion over the eastern and sinking motion over the western basin. As noted earlier, Nino3 is associated with little lower atmospheric variability over the adjoining Indian and Atlantic Oceans. However, as evidenced by high values of $p r_{n}$, the upper tropospheric zonal winds are strongly influenced over the Atlantic, but moderately over the Indian Ocean in association with Nino3.

It is interesting that the 'Walker' cell associated with IOD appears to have a weaker cell of opposing sign to its downstream with sinking motion over Indonesia and the western Pacific and rising motion over the central east Pacific. At $1000 \mathrm{mb}$, this downstream cell is accompanied by westerly wind anomalies that appear to propagate with time to the east (Fig. 12). The nature of the cells in the vertical plane (Fig. 11) and in the horizontal plane (Fig. 12) is suggestive of Kelvin wave dynamics. It is possible that the structures downstream are forced as a result of the modulated rainfall over the eastern Indian Ocean (Saji et al. 1999) and over western Indonesia (Table 3) during IOD events. Experiments (not shown) with a linear shallow-water Matsuno-Gill type model (Saji \& Goswami 1996) suggest that convective anomalies over the eastern Indian Ocean and over Sumatra may give rise to the observed zonal wind anomalies over the western Pacific. However, it is not clear how the slow eastward propagation is related to Kelvin wave dynamics, because the propagation speed is an order of magnitude slower compared to the free atmospheric Kelvin wave.

The values of $p r_{\mathrm{n}}$ in Fig. 12 suggest that El Niños that are independent of IOD events are associated with weak westerly anomalies in the late spring and summer and moderate easterly anomalies in late fall and later. This inference is supported by composite wind anomaly maps (not shown) during IOD-independent ENSO events (see Table 1).

A second region where IOD has strong correlations with zonal wind variability is the region of monsoon westerlies over the Arabian Sea and the Bay of Bengal. The following calculations using zonal wind anomaly averaged between 10 and $20^{\circ} \mathrm{N}$ at various atmospheric levels, seasons and longitudes were performed to 
a) IOD-zonal wind ASO

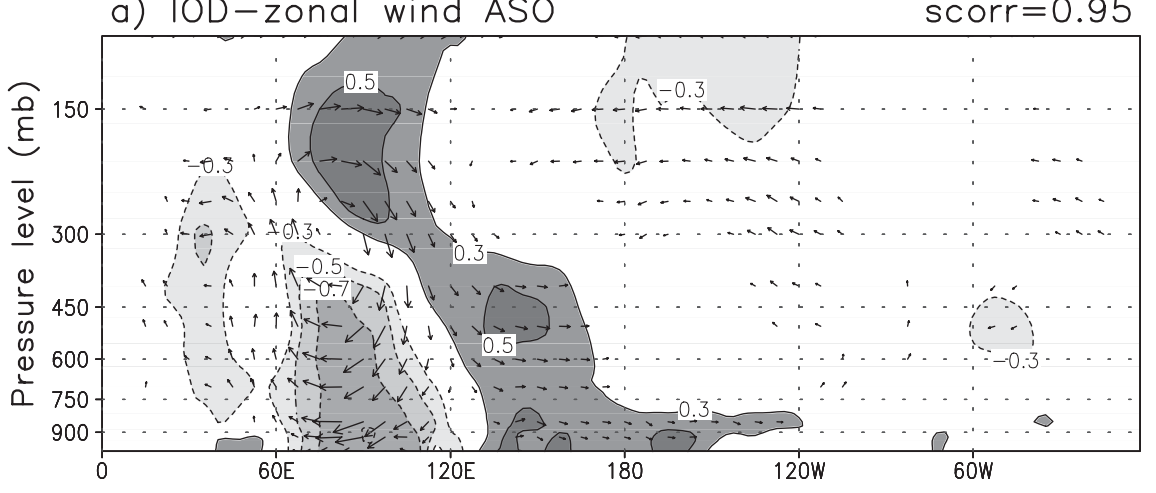

b) ENSO-zonal wind ASO scorr $=0.97$

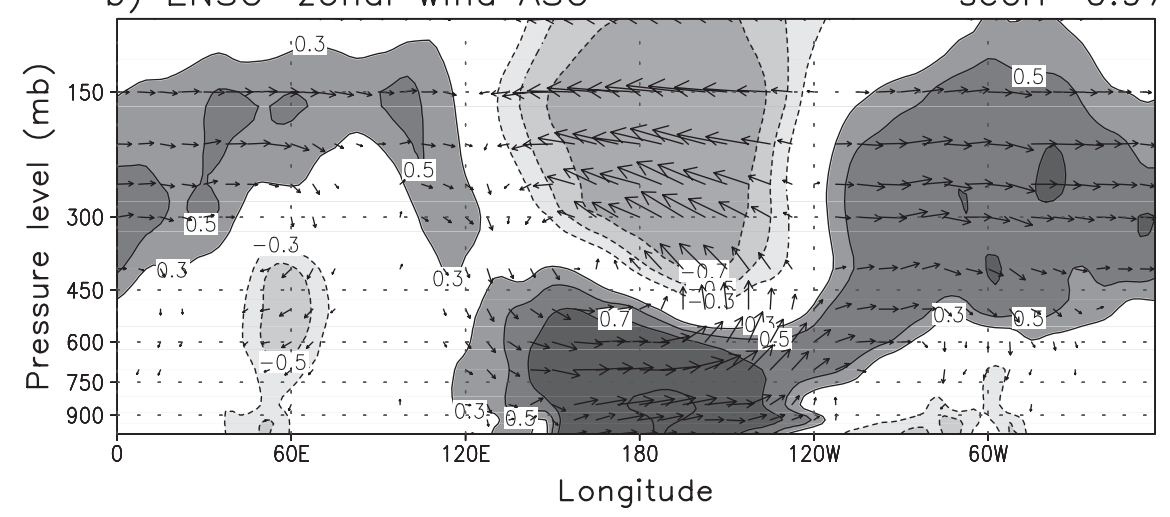

Fig. 11. Partial correlation of equatorial zonal wind anomaly (a) on DMI independent of Nino3 and (b) on Nino3 independent of DMI, as a function of longitude and height during ASO. Overlaid as vectors are partial linear regressions of zonal wind and vertical wind anomalies

bring out various aspects of the changes in these westerlies during IOD events.

Fig. 13 depicts the time-height section of the partial correlations at $90^{\circ} \mathrm{E}$, and Fig. 14 is the longitude-height section during JAS. From these figures it is clear that the monsoon westerlies are affected across the entire northern Indian Ocean, from the eastern edge of the monsoon westerlies at $40^{\circ} \mathrm{E}$ to its eastern edge at $120^{\circ} \mathrm{E}$ over the East China Sea, and over a deep vertical extent from 1000 to $300 \mathrm{mb}$. Considering climatology, this suggests a significant modulation of the vertical shear, since the lower layers (i.e. below $300 \mathrm{mb}$ ) are accelerated during positive IOD events relative to levels above it (where climatological winds are easterlies). Likewise, the horizontal wind shear is greatly affected by this configuration of anomalies. This results in an anomalous negative curl, especially over the southern Bay of Bengal and affects oceanic circulation and upwelling patterns significantly in that region (Han \& Webster 2002, Rao et al. 2002).

The maximum association of DMI with the monsoon westerlies is found over $90^{\circ} \mathrm{E}$, during JAS at $850 \mathrm{mb}$ with DMI accounting for about $64 \%$ of its variability. However, the effect of ENSO on these westerlies appear to be modest. Below $500 \mathrm{mb}$, we find negligible values of $p r_{n}$ over most regions, except for a small region of near-surface westerlies over the Arabian Sea. Stronger, extensive and persistent values of $p r_{n}$ are nevertheless noted in the upper levels.

A third important change in the atmospheric circulation over the tropical Indian Ocean during IOD events is the development of a meridional circulation (or 'Hadley') cell over the Bay of Bengal. This can be seen by examining the structure of the IOD correlations on meridional wind anomalies averaged between 98 and $108^{\circ} \mathrm{E}$ (Fig. 15).

At lower levels, DMI is positively correlated with meridional winds between $10^{\circ} \mathrm{S}$ and $10^{\circ} \mathrm{N}$, with the largest correlations at $5^{\circ} \mathrm{S}$ and $1000 \mathrm{mb}$ explaining about $64 \%$ of its variability. At the upper levels the negative values of $p r_{\mathrm{d}}$ imply a return flow occurring between $5^{\circ} \mathrm{S}$ and $20^{\circ} \mathrm{N}$. On the other hand values of $p r_{\mathrm{n}}$ are small at all levels, suggesting that ENSO does not appreciably modulate the monsoon Hadley circulation.

It was seen that on the whole there is an appreciable modulation of the equatorial and monsoonal circulation in association with IOD events. It is of interest to summarize and quantify these changes so that an 

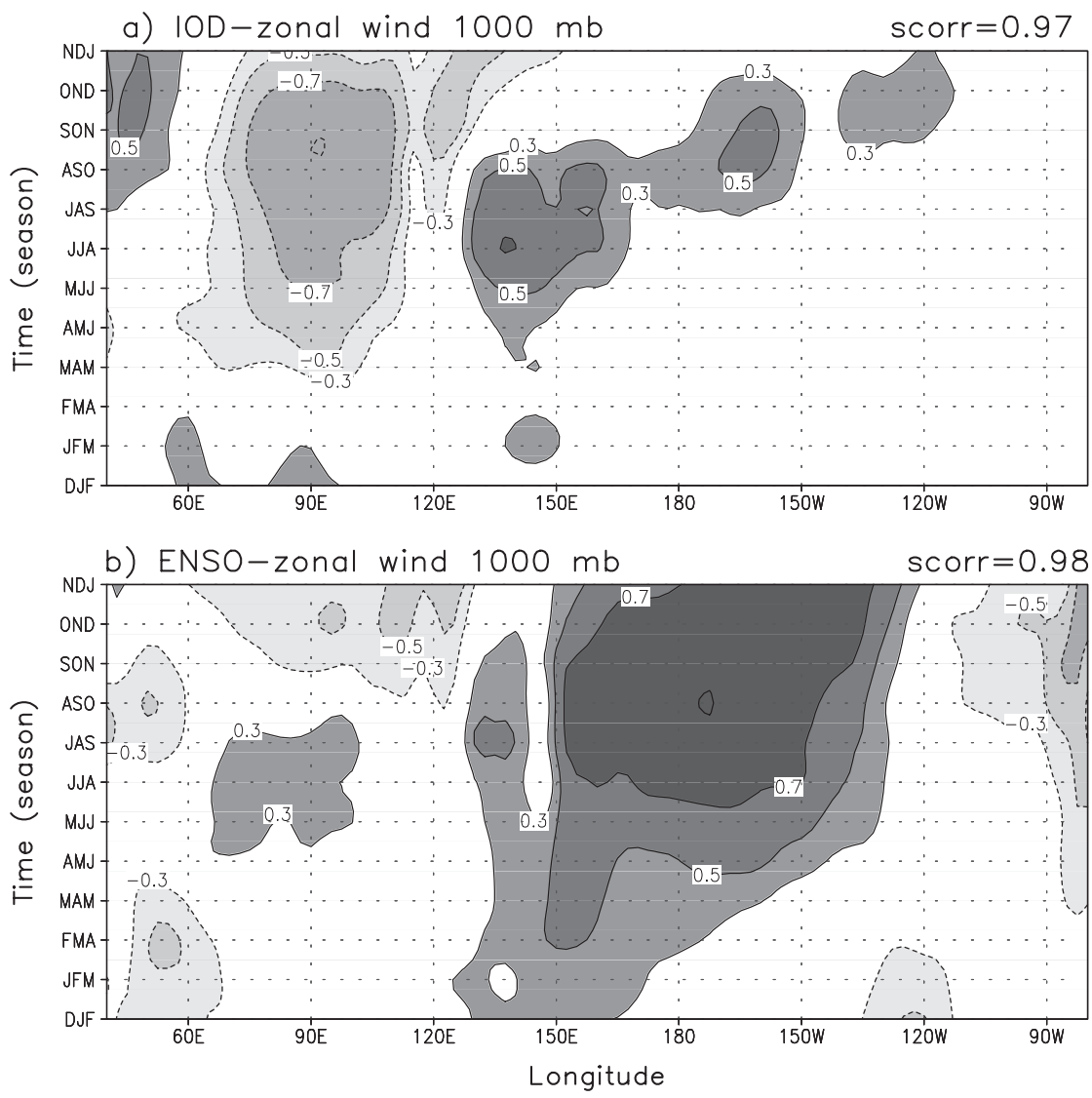

Fig. 12. Partial correlation of equatorial zonal wind anomaly at $1000 \mathrm{mb}$ (a) on DMI independent of Nino3 and (b) on Nino3 independent of DMI, as a function of longitude and season

appreciation of the impact of IOD to local circulation may be gained. It is also of importance to compare such an estimate to the contribution by ENSO. We performed the following calculations to this end.

Let $A$ be the percentage variance explained by DMI for a given variable at a particular longitude, latitude, height grid during a given season. Let $N$ be the observed variance in the variable observed at this space-time point. Then, $A \times N$ is the total variance associated with DMI at this point. We first averaged $A \times N$ between 50 and $120^{\circ} \mathrm{E}$. Let this quantity be denoted $C$. The mass-weighted integral of $C$ from sea level up to $150 \mathrm{mb}$ was then calculated. This is then an estimate of the contribution to this variable by DMI over the Indian Ocean, expressed as a function of latitude. Such estimates were separately made using zonal and meridional wind anomalies during JJA and SON for both DMI and Nino3.

In Fig. 16, the shading indicates the joint contribution of IOD and ENSO to zonal and meridional wind variability respectively, over the Indian Ocean during JJA. Fig. 17 is similar except that it describes the contributions during SON. A significant part of the zonal wind variability is jointly contributed by the 2 phenomena, with the contributions varying with latitude and season. In the near-equatorial region between $10^{\circ} \mathrm{N}$ and $10^{\circ} \mathrm{S}$, the largest contribution is about $45 \%$ during SON. This is nearly twice the contribution during JJA and is consistent with the evolution of both phenomena. Significant contributions to the zonal wind variance around $15^{\circ} \mathrm{N}$ and $15^{\circ} \mathrm{S}$ are noted during both seasons, with both phenomena jointly contributing about 30 to $40 \%$. However both phenomena only moderately contributes to the meridional wind variance.

The ratios between IOD and ENSO contributions are plotted in Figs. $16 \& 17$. It is clear that at most latitudes over the Indian Ocean, the IOD contribution dominates over that due to ENSO. The predominance of IOD over ENSO to zonal wind variance is noticeable over the equatorial belt during both JJA and SON, with IOD contributing more than 2.5 times the ENSO contribution during SON. As noted before, the monsoon westerlies around $15^{\circ} \mathrm{N}$ are predominantly controlled by IOD during the summer monsoon season. However, around $15^{\circ} \mathrm{S}$ during JJA and SON, the IOD contribution is only half as that of ENSO. We also note that the meridional wind variance is predominantly controlled by IOD over most latitude belts during both JJA and SON. 


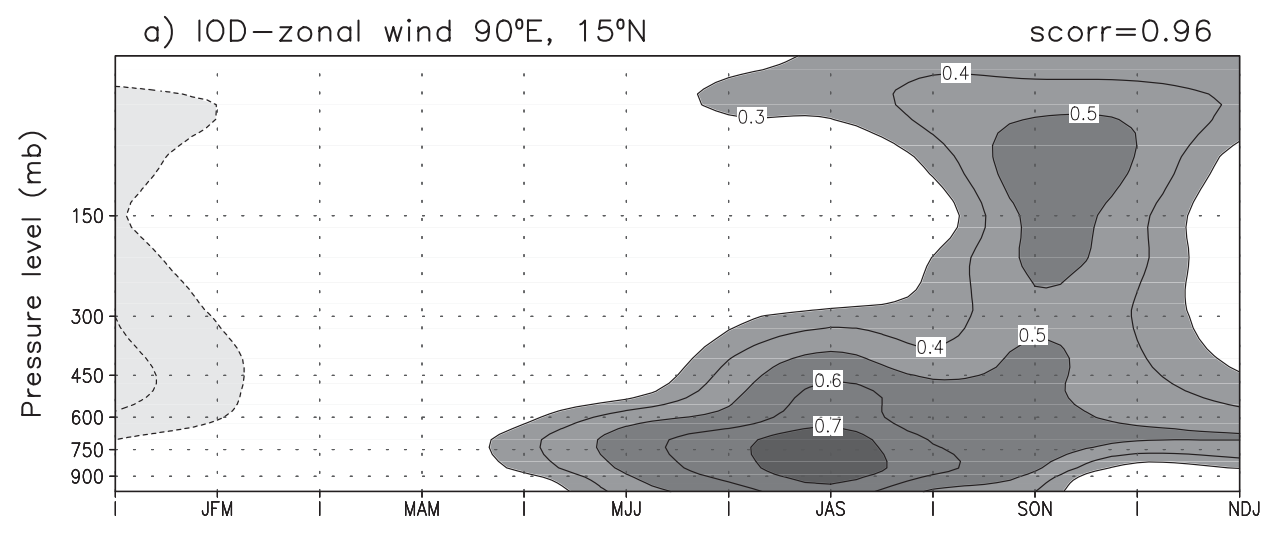

b) ENSO-zonal wind $90^{\circ} \mathrm{E}, 15^{\circ} \mathrm{N}$

scorr $=0.96$

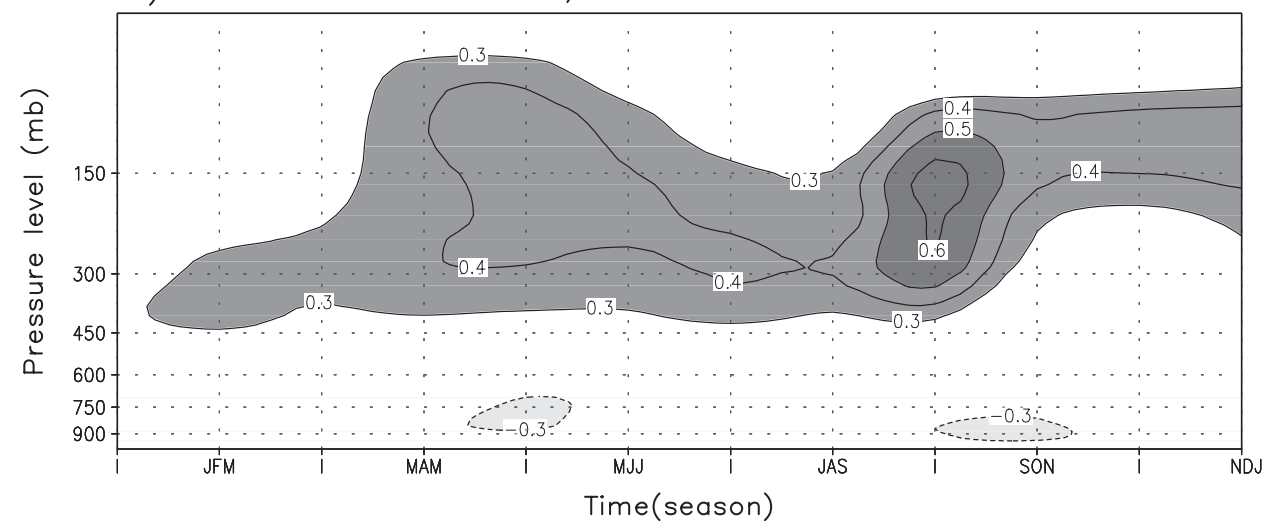

Fig. 13. Partial correlation of zonal wind anomaly at $90^{\circ} \mathrm{E}, 15^{\circ} \mathrm{N}$ (a) on DMI independent of Nino3 and (b) on Nino3 independent of DMI, as a function of season and atmospheric level

\subsection{Extra-tropical variability}

Extra-tropical atmospheric variability associated with IOD has distinctly different structures in the northern and southern hemispheres. The northern extratropical anomalies have a near-annular structure, with positive anomalies around $40^{\circ} \mathrm{N}$ extending zonally from Europe to North America.

In Fig. 18 we have plotted the values of $p r_{\mathrm{d}}$ and $p r_{\mathrm{n}}$ for $200 \mathrm{mb}$ height anomalies averaged between 35 and $50^{\circ} \mathrm{N}$, as a function of longitude. The largest correlation with DMI as well as Nino3 is noted over NE Asia during JAS. While DMI has a positive correlation with the height anomaly, Nino3 is negatively correlated with it. Significant correlations with both DMI and Nino3, but of opposing sign, are noted also over North America and Europe. Thus, like IOD, ENSO is also associated with a annular-like distortion of the $200 \mathrm{mb}$ height in the northern extra-tropics.

The annular-like anomalies of $200 \mathrm{mb}$ height have an equivalent barotropic structure and appear during early boreal summer. This can be seen by examining values of $p r_{\mathrm{d}}$ and $p r_{\mathrm{n}}$ for the extratropical height anomalies at $130^{\circ} \mathrm{E}$ (Fig. 19). Positive (negative) values of $p r_{\mathrm{d}}$ $\left(p r_{\mathrm{n}}\right)$ are observed from about $750 \mathrm{mb}$ to the upper levels of the troposphere. The strongest correlation with DMI is observed at $150 \mathrm{mb}$ during JAS $(\mathrm{r}=0.52)$. Such vertical structure and temporal evolution are evident over the other regions in the northern extratropics too.

However in the southern hemisphere, wave-like trains are observed over the extratropics in association with IOD. Fig. 20 provides an overview of the differences in the northern and southern extratropical structures correlated with DMI. We used the combined season JJASO, since during both JJA and ASO the teleconnection patterns were identical; however, the extended averaging brought out slightly stronger correlations.

A prominent structure over the southern extratropics is the wave-like train that is apparently generated over the south eastern Indian Ocean and extends downstream in an arcing manner into the south Pacific and Atlantic. East of $120^{\circ} \mathrm{W}$ the wave train re-curves into the equator and extends over into South America and South Africa. Another wave train extends from over Australia in a more or less zonal orientation into South America. As in the northern extratropics, the height anomalies associated with these wave-like trains have an equivalent barotropic structure (not shown). 
a) IOD-zonal wind JAS, $15^{\circ} \mathrm{N}$

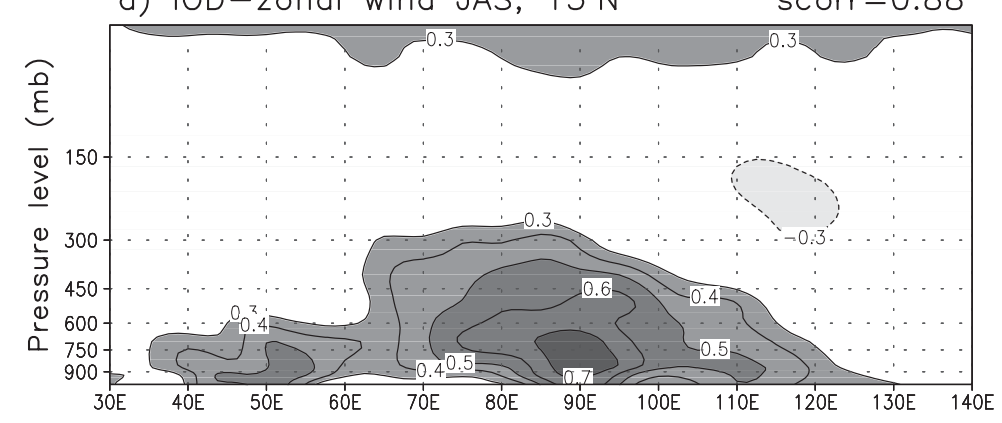

b) ENSO-zonal wind JAS, $15^{\circ} \mathrm{N}$

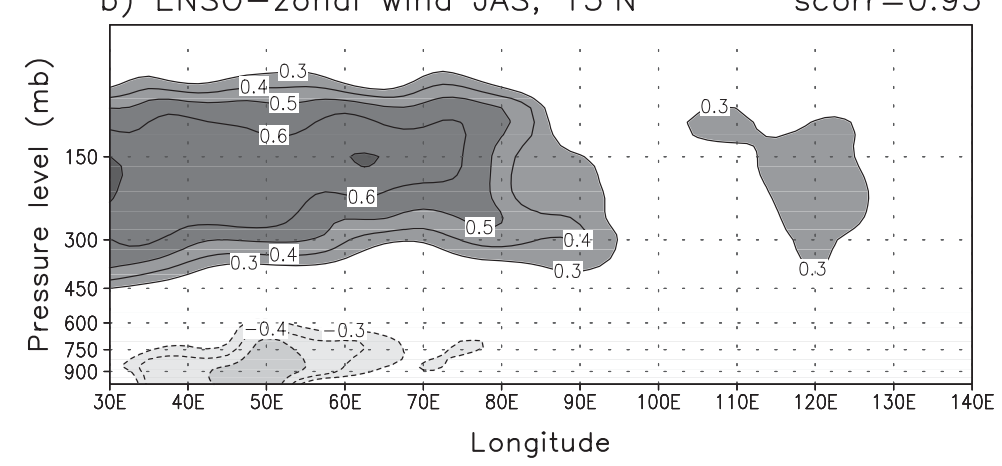

Fig. 14. Partial correlation of zonal wind anomaly at $15^{\circ} \mathrm{N}$ during JAS (a) on DMI independent of Nino3 and (b) on Nino3 independent of DMI, as a function of longitude and atmospheric level

a) IOD-meridional wind, $103^{\circ} \mathrm{E}, \mathrm{JAS}$

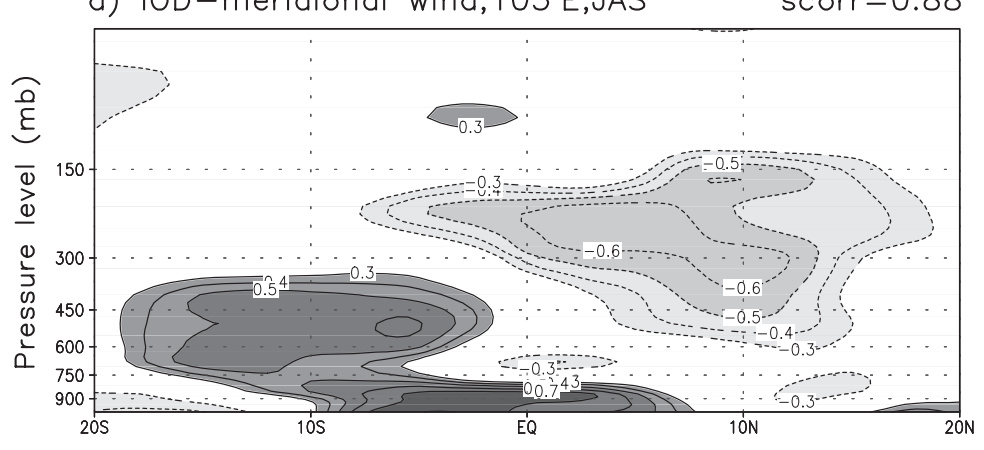

b) ENSO-meridional wind, $103^{\circ} \mathrm{E}, \mathrm{JAS}$

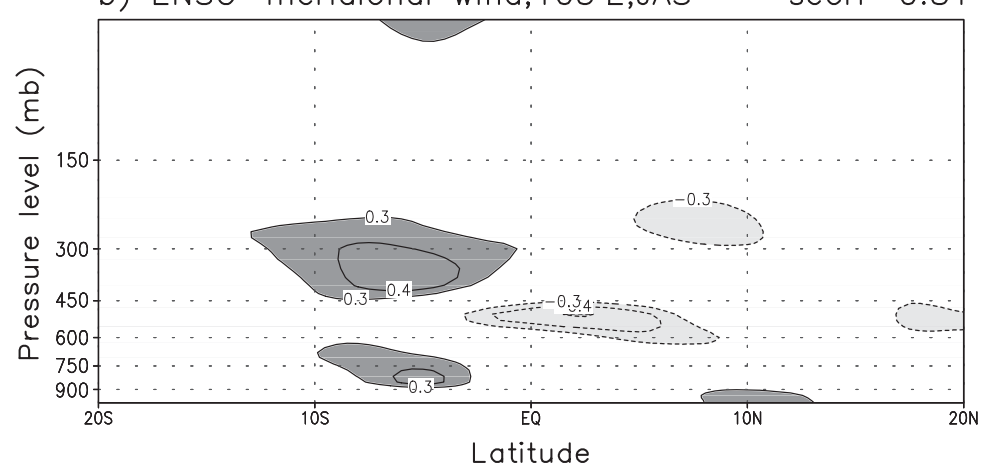

Fig. 15. Partial correlation of meridional wind anomaly at $103^{\circ} \mathrm{E}$ during JAS (a) on DMI independent of Nino3 and (b) on Nino3 independent of DMI, as a function of latitude and atmospheric level

\section{DISCUSSION}

The significant correlations of DMI on worldwide temperature, rain and atmospheric circulation anomalies are indicative of the importance of IOD events to global climate. It is noteworthy that these correlations are not haphazard, but exhibit rather well-defined structures that are consistent among the various independent fields. We shall briefly comment on the nature of the IOD correlations in the various fields and their interrelations below.

Let us first consider the signal of IOD on land surface temperature. In the tropical regions surrounding the Indian Ocean, a clear pattern is of warm temperature anomalies over land regions to the west and cool anomalies over regions to the east of the Indian Ocean (Table 2, Fig. 21). This structure is likely a reflection of similar anomalies in the adjacent SSTs (Fig. 21). In turn, anomalies in SST are related to the 'Walker cell' in the equatorial Indian Ocean (Figs. 10-12). For instance, the surface easterly wind anomaly over the central equatorial Indian Ocean would lead to a shallowing of the thermocline to its east and a deepening to its west through equatorial wave dynamics (Ansell 2001, Rao et al. 2002). This in turn would modulate normal entrainment, upwelling and advective patterns (Murtugudde et al. 2000) and likely generates the SST anomaly signal of IOD. The anomalies in SST further may maintain the observed wind anomalies (Webster et al. 1999, Iizuka et al. 2000, Ashok et al. 2001).

The signal of IOD on rain over Indian Ocean rim countries also has interesting structures. Two prominent structures can be inferred from Table 3. In the largest of these patterns, rain is anomalously high over countries to the west of the Indian Ocean and anomalously low over countries to its east. This structure again is consistent with the underlying SST anomalies: cool SST anomalies lead to less evaporation and less rain, and warm SST anomalies lead to enhanced evaporation and more rain. Further, they are consistent with the atmospheric circulation anomalies: more rain where there is anomalous surface convergence and updrafts, and less rain where there is anomalous surface divergence and downdrafts (see Fig. 11). A second interesting pattern is of enhanced rain over the monsoon trough, extending from Pakistan up to southern China. This is consistent (Wang \& Fan 1999, Goswami et al. 2003) with the increased vertical and horizontal shear of the monsoon currents during IOD events, noted earlier.

Over the extratropics, IOD is associated with warm temperature anomalies, reduced rainfall and 
a) Zonal wind, JJA

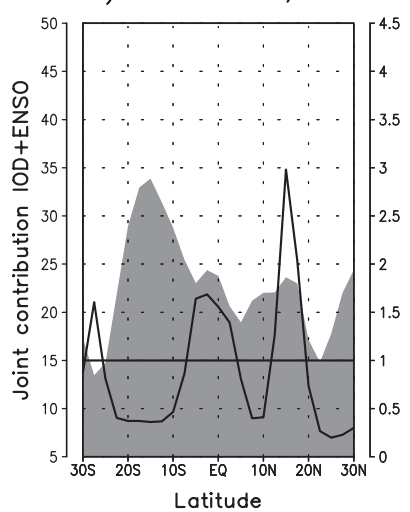

b) Meridional wind, JJA

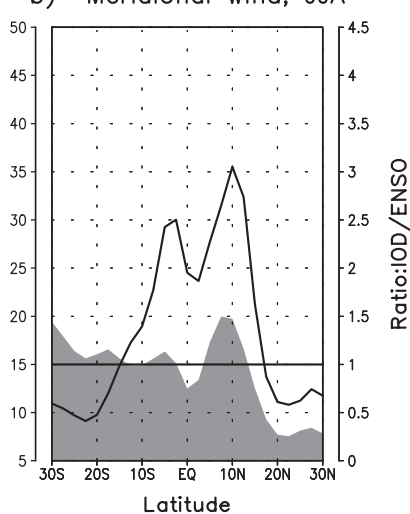

Fig. 16. Joint contribution by IOD and ENSO to (a) zonal wind variance and (b) meridional wind variance during JJA, expressed as a percentage of the total variance (grey shading). Solid lines: ratio of the contribution of IOD to that of ENSO

positive height anomalies. These relations again are consistent among each other. Positive height anomalies indicate anticyclonic circulation anomalies, which further imply clear skies and enhanced radiation and thus warmer land surface temperatures (Enomoto 2000, Norris 2000).

Over the southern extratropics, the observed structures are in qualitative agreement with the teleconnection studies of Ambrizzi \& Hoskins (1997) and Ambrizzi et al. (1995), who showed that tropical divergence anomalies in the southern Indian Ocean can lead to upper level teleconnections by Rossby wave propagation. Further, they predicted that such Rossby wave propagation would be channeled along the subpolar and subtropical jet streams, which again is in qualitative agreement with Fig. 20.

a) Zonal wind, SON

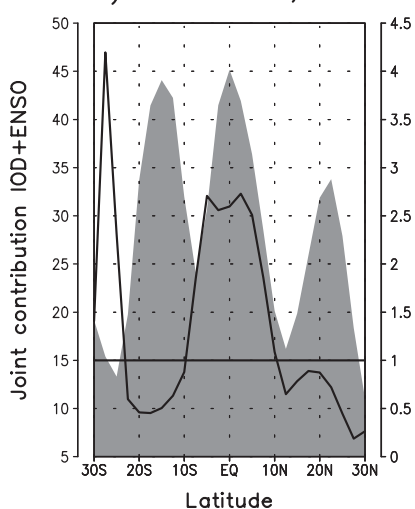

Fig. 17. Joint contribution by IOD and ENSO to (a) zonal wind variance and (b) meridional wind variance during SON, expressed as a percentage of the total variance (grey shading). Solid lines: ratio of the contribution of IOD to that of ENSO

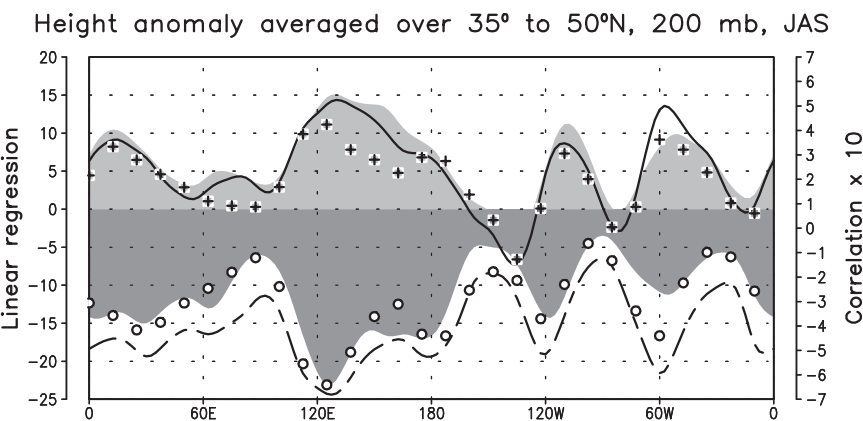

Fig. 18. Partial regression (correlation, $p r_{\mathrm{d}}$ ) of geopotential height anomaly averaged between 35 and $50^{\circ} \mathrm{N}$ at $200 \mathrm{mb}$ during JAS on DMI independent of Nino3 [light-grey fill (black line)], and partial regression (correlation, $p r_{n}$ ) of height on Nino3 independent of DMI [dark-grey fill (dashed line)]. $+(0)$ : values of $p r_{d}\left(p r_{n}\right)$ using unfiltered data. Value of the correlation coefficient is multiplied by 10

However, it is not clear how tropical circulation changes associated with IOD may force the extratropical signature in the northern hemisphere. It is to be noted that the configuration of the upper-level zonal winds are not favourable for the propagation of energy into the northern extratropics (Hoskins \& Karoly 1981) through stationary wave propagation directly out of the tropical Indian Ocean. Other potential mechanisms, such as the Monsoon-desert mechanism of

a) IOD-Height, $130^{\circ} \mathrm{E}$ scorr $=0.97$

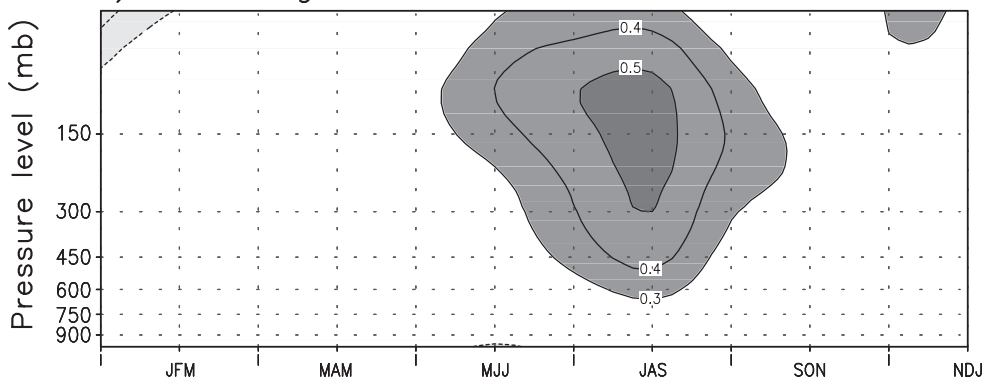

b) ENSO-Height, $130^{\circ} \mathrm{E}$ scorr $=0.97$

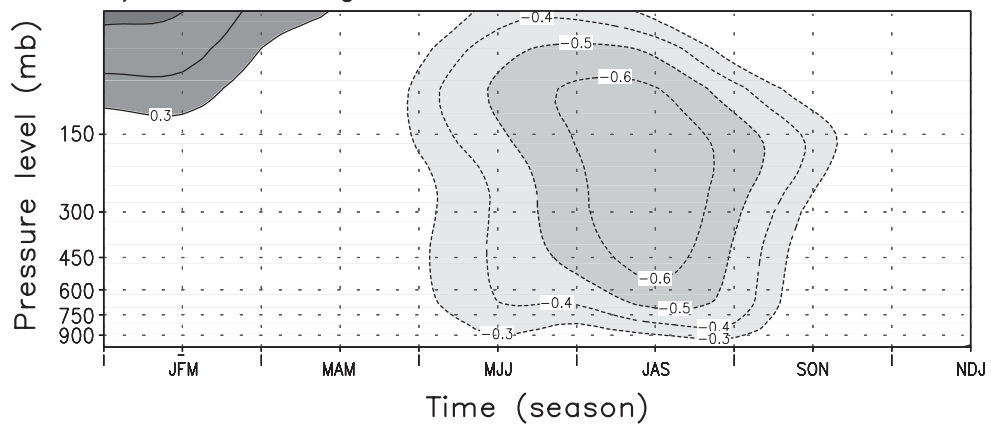

Fig. 19. Partial correlation of geopotential height anomaly at $130^{\circ} \mathrm{E}, 42^{\circ} \mathrm{N}$ (a) on DMI independent of Nino3 and (b) on Nino3 independent of DMI, as a function of season and atmospheric level 
Linear regression of $200 \mathrm{mb}$ wind on DMI for JJASO

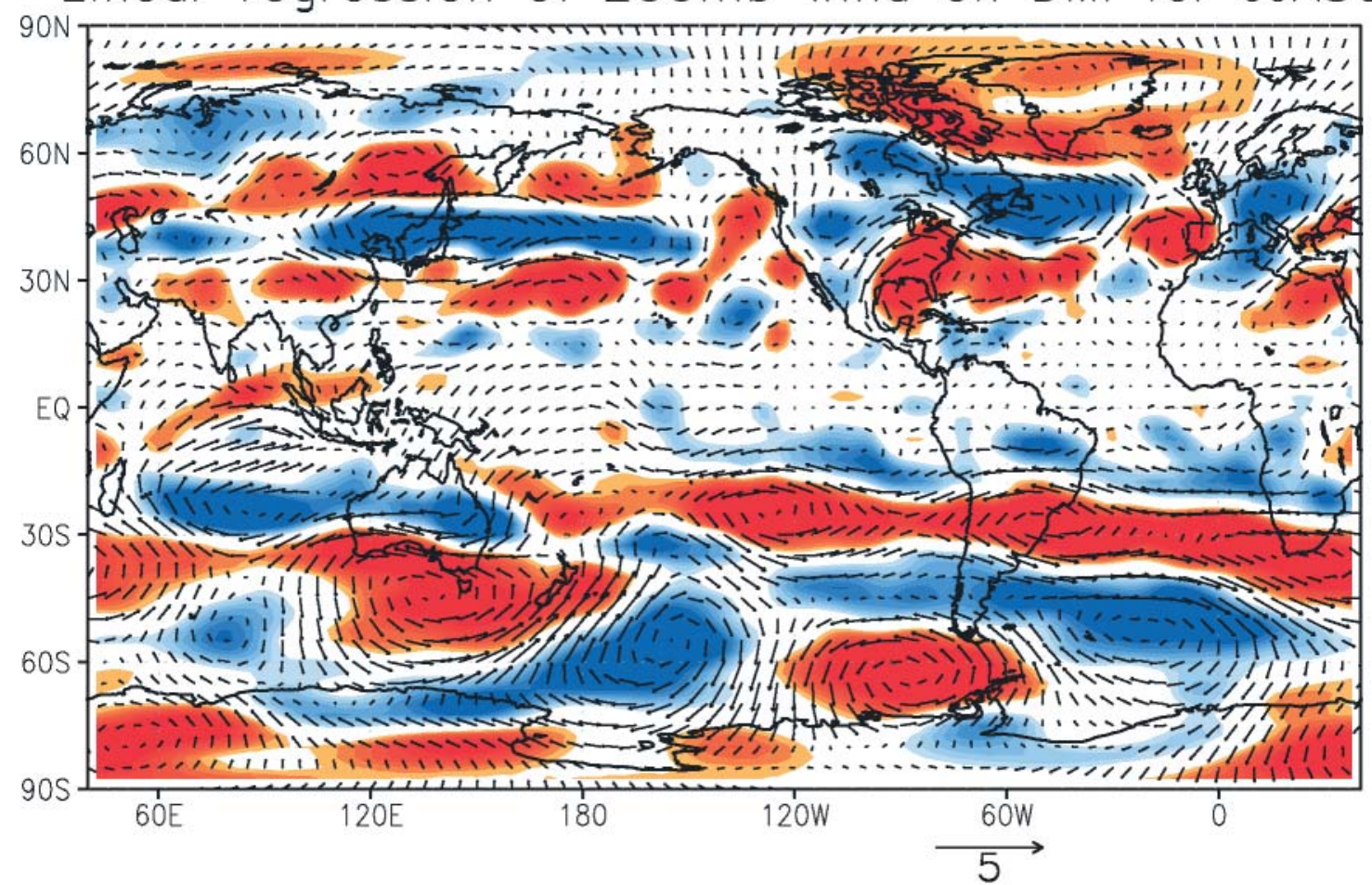

Fig. 20. Partial regression of $200 \mathrm{mb}$ wind anomaly on DMI independent of Nino3 (vectors). Blue (red) shading: negative (positive) curl associated with this wind field

IOD associated surface temperature anomaly; JJASO

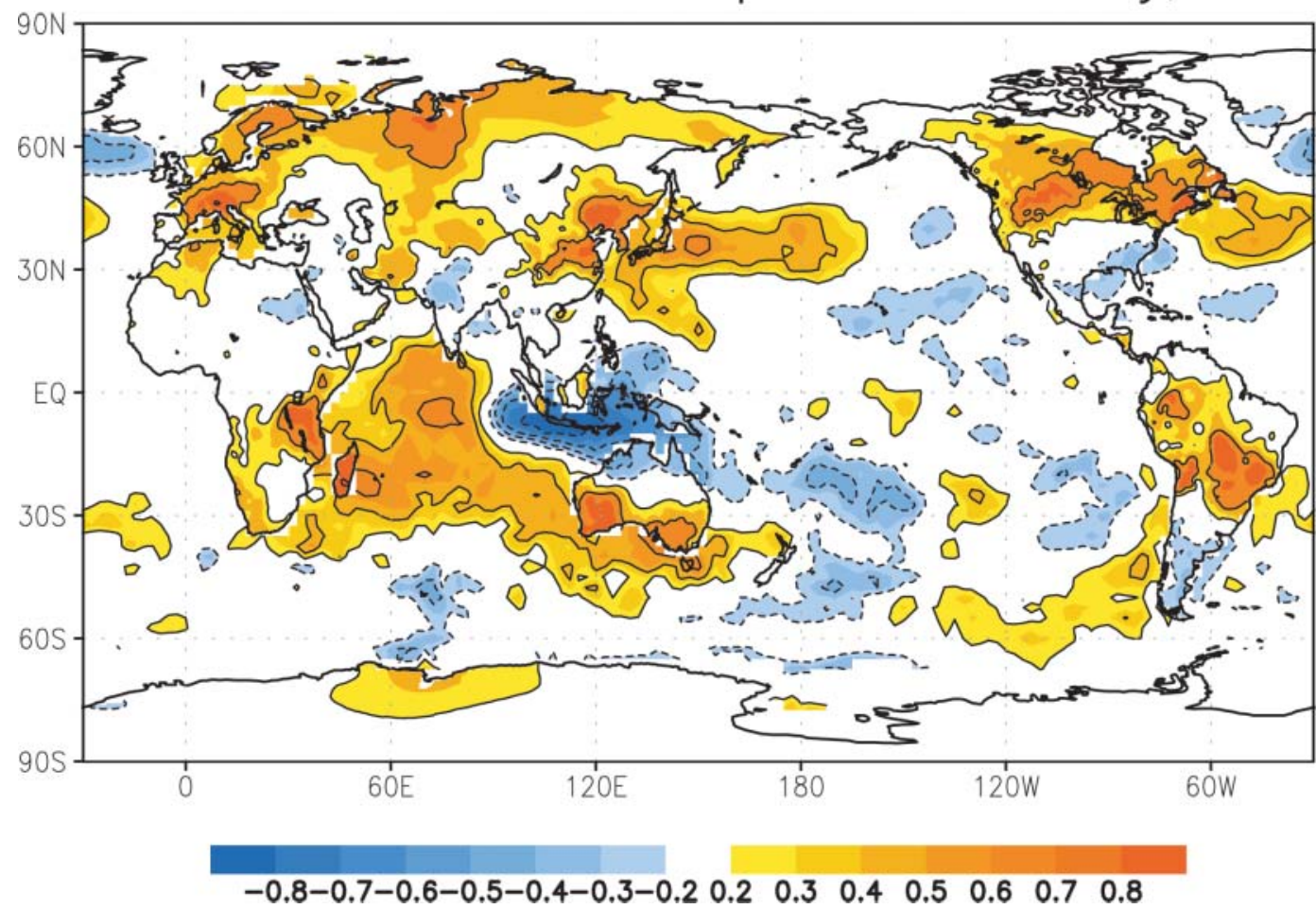

Fig. 21. Partial correlation of land and sea-surface temperature on DMI independent of Nino3 during JJASO 
Rodwell \& Hoskins (1996) and Enomoto (2000), and the 'Pacific-Japan' pattern of Nitta (1987), need to be considered.

It needs to be understood why teleconnection patterns associated with IOD and ENSO have similar but oppositely signed structures over several regions, mostly in the northern extra-tropics. A possible explanation is that the mid-latitude response is essentially modal in character (Ting \& Sardeshmukh 1993) and dominated by a single spatial pattern. The oppositely signed structures are likely due to the existence of a nodal line in the forcing, as suggested in some studies (Ting \& Sardeshmukh 1993, Barsugli \& Sardeshmukh 2003), such that forcing slightly west or east of this nodal line results in responses of opposite sign.

Acknowledgements. Preliminary discussions with Prof. B. N. Goswami are gratefully acknowledged. Prof. J. M. Wallace generously made several constructive suggestions during his visit to FRSGC. We also thank Prof. S. P. Xie and Dr. T. Enomoto for their critical comments. The manuscript benefitted greatly from the critical comments of the 2 anonymous reviewers and Dr. G. Meyers. Thanks to Mr. Yingshuo Shen for help with the Monte Carlo techniques. Part of the work was completed at the IPRC. The IPRC is supported by institutional grants from the Frontier Research System for Global Change, Japan and from the National Aeronautic and Space Administration and the National Oceanic and Atmospheric Administration. This is IPRC contribution No. 220.

\section{LITERATURE CITED}

Ambrizzi T, Hoskins B (1997) Stationary Rossby-wave propagation in a baroclinic atmosphere. Q J R Meteorol Soc 123: 919-928

Ambrizzi T, Hoskins B, Hsu HH (1995) Rossby wave propagation and teleconnection patterns in the austral winter. J Atmos Sci 52:3661-3672

Ansell T (2001) Air-sea interaction in the SE Indian Ocean and links with SE Australian winter rainfall variability. $\mathrm{PhD}$ thesis, School of Earth Sciences, University of Melbourne, Parkville

Ashok K, Guan Z, Yamagata T (2001) Impact of the Indian Ocean Dipole on the relationship between the Indian monsoon rainfall and ENSO. Geophys Res Lett 28:4499-4502

Barsugli JJ, Sardeshmukh PD (2003) Global atmospheric sensitivity to tropical SST anomalies throughout the IndoPacific Basin. J Clim 50:907-918

Behera SK, Yamagata T (2003) Impact of the Indian Ocean Dipole on the Southern Oscillation. J Meteorol Soc Jpn 81: 169-177

Behera SK, Krishnan S, Yamagata T (1999) Anomalous air-sea coupling in the southern tropical Indian Ocean during the boreal summer of 1994. Geophys Res Lett 26: 3001-3004

Black E, Slingo J, Sperber KR (2003) An observational study of the relationship between excessively strong short rains in coastal East Africa and Indian Ocean SST. Mon Weather Rev 131:74-94

Chiang JCH, Sobel AH (2002) Tropical tropospheric temperature variations caused by ENSO and their influence on remote tropical climate. J Clim 15:2616-2631
Clark CO, Webster PJ, Cole JE (2003) Interdecadal variability of the relationship between the Indian Ocean Zonal Mode and East African coastal rainfall anomalies. J Clim 16: $548-554$

Cohen J, Cohen P (1983) Applied multiple regression/correlation analysis for the behavioral sciences. Lawrence Erlbaum Associates, Hillsdale, NJ

Enomoto T (2000) The formation mechanism for the equivalent-barotropic structure of the Bonin high. PhD thesis, Department of Earth and Planetary Science, University of Tokyo

Feng M, Meyers G (2003) Interannual variability in the tropical Indian Ocean: a two-year time scale of IOD. Deep-Sea Res II 50:2263-2284

Gill AE (1980) Some simple solutions for heat-induced tropical circulations. Q J R Meteorol Soc 106:447-462

Goddard L, Graham NE (1999) The importance of the Indian Ocean for simulating rainfall anomalies over Eastern and Southern Africa. J Geophys Res 104:19099-19116

Goswami BN, Ajayamohan RS, Xavier PK, Sengupta D (2003) Clustering of synoptic activity by Indian summer monsoon intraseasonal oscillations. Geophys Res Lett 30 (DOI: 10.1029/2002 GL 016734)

Guan Z, Yamagata T (2003) The unusual summer of 1994 in East Asia: IOD teleconnections. Geophys Res Lett 30 (DOI: 10.29/2002 GL 016831)

Han WQ, Webster PJ (2002) Forcing mechanisms of sea level interannual variability in the Bay of Bengal. J Phys Oceanogr 32:216-239

Hastenrath S, Nicklis A, Greischar L (1993) Atmospherichydrospheric mechanisms of climate anomalies in the western equatorial Indian Ocean. J Geophys Res 98: 20219-20235

Hendon HH (2003) Indonesian rainfall variability: impacts of ENSO and local air-sea interaction. J Clim 16: $1775-1790$

Hoskins BJ, Karoly D (1981) The steady linear response of a spherical atmosphere to thermal and orographic forcing. J Atmos Sci 38:1179-1196

Iizuka S, Matsuura T, Yamagata T (2000) The Indian Ocean SST dipole simulated in a Coupled General Circulation Model. Geophys Res Lett 27:3369-3372

Kalnay E, Kanamitsu M, Kistler R, Collins W and 18 others (1996) The NCEP/NCAR 40-year reanalysis project. Bull Am Meteorol Soc 77:437-471

Klein SA, Soden BJ, Lau NC (1999) Remote sea surface temperature variations during ENSO: evidence for a tropical atmospheric bridge. J Clim 12:917-932

Lareef Z, Rao AS, Yamagata T (2003) Modulation of Sri Lankan Maha rainfall by the Indian Ocean Dipole. Geophys Res Lett 30 (DOI: 10.1029/2002 GL 015639)

Li T, Zhang Y, Lu E, Wang D (2002) Relative role of dynamic and thermodynamic processes in the development of the Indian Ocean dipole: an OGCM diagnosis. Geophys Res Lett 29 (DOI: 10.1029/2002 GL 015789)

Livezey RE, Chen WY (1983) Statistical field significance and its determination by Monte Carlo techniques. Mon Weather Rev 111:46-59

Lobitz B, Beck L, Huq A, Wood B, Fuchs G, Faruque A (2000) Climate and infectious disease: use of remote sensing for detection of Vibrio cholera by indirect measurement. Proc Natl Acad Sci USA 97:1438-1443

Matsuno T (1966) Quasi-geostrophic motions in the equatorial area. J Meteorol Soc Jpn 44:25-42

McCreary J, Anderson DT (1984) Simple models of the El Nino and Southern Oscillation. Mon Weather Rev 112: 934-946 
Murtugudde RG, Signorini SR, Christian JR, Busalacchi A, McClain CR, Picaut J (1999) Ocean color variability of the tropical Indo-Pacific basin observed by SeaWiFS during 1997-1998. J Geophys Res 104:18351-18366

Murtugudde RG, McCreary JP, Busalacchi AJ (2000) Oceanic processes associated with anomalous events in the Indian Ocean with relevance to 1997-1998. J Geophys Res 105: 3295-3306

Mutai CC, Ward MN (2000) East African rainfall and the tropical circulation/convection on intraseasonal to interannual timescales. J Clim 13:3915-3939

Nakamura H, Lin G, Yamagata T (1997) Decadal climate variability in the North Pacific during the recent decades. Bull Am Meteorol Soc 78:2215-2225

Nitta T (1987) Convective activities in the tropical western Pacific and their impact on the Northern Hemisphere summer circulation. J Meteorol Soc Jpn 65:373-390

Norris JR (2000) Interannual and interdecadal variability in the storm track, cloudiness and sea surface temperature over the summertime North Pacific. J Clim 13:422-430

Pan HY, Oort AH (1983) Global climate variations associated with sea surface temperature anomalies in the eastern equatorial Pacific Ocean for the 1958-1973 period. Mon Weather Rev 111:1244-1258

Panofsky HA, Brier GW (1958) Some applications of statistics to meteorology. Pennsylvania State University, University Park

Rao AS, Behera SK, Masumoto Y, Yamagata T (2002) Interannual variability in the subsurface tropical Indian Ocean. Deep-Sea Res II 49:1549-1572

Rayner NA, Horton EB, Parker DE, Folland CK, Hackett RB (1996) Version 2.2 of the global sea-ice and sea surface temperature data set 1903-1994. Hadley Centre Tech Rep CRTN 74, Met Office, Bracknell

Reverdin G, Cadet DL, Gutzler D (1986) Interannual displacements of convection and surface circulation over the equatorial Indian Ocean. Q J R Meteorol Soc 112:43-67

Rodwell MJ, Hoskins BJ (1996) Monsoons and dynamics of deserts. Q J R Meteorol Soc 122:1385-1404

Editorial responsibility: Hans von Storch, Geesthacht, Germany
Saji NH, Goswami BN (1996) An improved linear model of tropical surface wind variability. Q J R Meteorol Soc 122:23-54

Saji NH, Yamagata T (2003) Structure of SST and surface wind variability during Indian Ocean Dipole Mode years: COADS observations. J Clim 16:2735-2751

Saji NH, Goswami BN, Vinayachandran PN, Yamagata T (1999) A dipole mode in the tropical Indian Ocean. Nature 401:360-363

Schouten MW, de Ruijter WPM, van Leeuwen PJ, Dijkstra HA (2002) An oceanic teleconnection between the equatorial and southern Indian Ocean. Geophys Res Lett 29 (DOI: 10.1029/2001 GL 014542)

Ting M, Sardeshmukh PD (1993) Factors determining the extratropical response to equatorial diabatic heating anomalies. J Atmos Sci 50:907-918

Vinayachandran PN, Saji NH, Yamagata T (1999) Response of the Equatorial Indian Ocean to an unusual wind event during 1994. Geophys Res Lett 26:1613-1616

Wallace JM, Rasmusson EM, Mitchell TP, Kousky VE, Sarachik ES, von Storch H (1998) On the structure and evolution of ENSO-related climate variability in the tropical Pacific. J Geophys Res 103:14241-14260

Wang B, Fan Z (1999) Choice of South Asian summer monsoon indices. Bull Am Meteorol Soc 80:629-638

Webster PJ, Moore AM, Loschnigg JP, Leben RR (1999) Coupled ocean-atmosphere dynamics in the Indian Ocean during 1997-98. Nature 401:356-360

Willmott CJ, Matsuura K (1995) Smart interpolation of annually averaged air temperature in the United States. J Appl Meteorol 34:2557-2586

Xie P, Arkin PA (1996) Analyses of global monthly precipitation using gauge observations, satellite estimates and numerical model predictions. J Clim 9:840-858

Xie SP, Annamalai H, Schott FA, McCreary JP (2002) Structure and mechanisms of South Indian Ocean climate variability. J Clim 15:864-878

Zorita E, Tilya FF (2002) Rainfall variability in Northern Tanzania in the March-May season (long rains) and its links to large-scale climate forcing. Clim Res 20:31-40

Submitted: July 16, 2002; Accepted: July 4, 2003

Proofs received from author(s): October 6, 2003 